\title{
Regulation of Agronomic Traits, Nutrient Uptake, Osmolytes and Antioxidants of Maize as Influenced by Exogenous Potassium Silicate under Deficit Irrigation and Semiarid Conditions
}

\author{
Mohamed F. M. Ibrahim ${ }^{1}$ **1) , Gomaa Abd El-Samad ${ }^{2}$, Hatem Ashour ${ }^{1}$, Ahmed M. El-Sawy ${ }^{3}$, \\ Mohamed Hikal ${ }^{4}$, Amr Elkelish 5,*(D), Hany Abd El-Gawad 6,*(D), Ahmed Abou El-Yazied ${ }^{6}$, \\ Wael N. Hozzein ${ }^{7,8}$ (D) and Reham Farag ${ }^{1}$ \\ 1 Department of Agricultural Botany, Faculty of Agriculture, Ain Shams University, Cairo 11566, Egypt; \\ Hatem_ashour@agr.asu.edu.eg (H.A.); Reham_hassan@agr.asu.edu.eg (R.F.) \\ 2 Department of Agronomy, Faculty of Agriculture, Ain Shams University, Cairo 11566, Egypt; \\ Gomaa_abdelsamad@agr.asu.edu.eg \\ 3 Climate Modification Department, Central Laboratory for Agriculture Climate, Agriculture Research Center, \\ Giza 12411, Egypt; ahmed.elsawy@arc.sci.eg \\ 4 Department of Biochemistry, Faculty of Agriculture, Ain Shams University, Cairo 11566, Egypt; \\ Mohamed_elsayed4@agr.asu.edu.eg \\ 5 Botany Department, Faculty of Science, Suez Canal University, Ismailia 41522, Egypt \\ 6 Department of Horticulture, Faculty of Agriculture, Ain Shams University, Cairo11566, Egypt; \\ ahmed_abdelhafez2@agr.asu.edu.eg \\ 7 Bioproducts Research Chair, Zoology Department, College of Science, King Saud University, \\ Riyadh 11451, Saudi Arabia; whozzein@ksu.edu.sa \\ 8 Botany and Microbiology Department, Faculty of Science, Beni-Suef University, Beni-Suef 62511, Egypt; \\ * Correspondence: Ibrahim_mfm@agr.asu.edu.eg (M.F.M.I.); amr.elkelish@science.suez.edu.eg (A.E.); \\ hany_gamal2005@agr.asu.edu.eg (H.A.E.-G.); Tel.: +2-01123403173 (M.F.M.I.)
}

Received: 16 July 2020; Accepted: 10 August 2020; Published: 18 August 2020

\begin{abstract}
Understanding the link between the protective role of potassium silicate $\left(\mathrm{K}_{2} \mathrm{SiO}_{3}\right)$ against water shortage and the eventual grain yield of maize plants is still limited under semiarid conditions. Therefore, in this study, we provide insights into the underlying metabolic responses, mineral nutrients uptake and some nonenzymatic and enzymatic antioxidants that may differ in maize plants as influenced by the foliar application of $\mathrm{K}_{2} \mathrm{SiO}_{3}(0,1$ and $2 \mathrm{mM})$ under three drip irrigation regimes $(100,75$ and $50 \%$ of water requirements). Our results indicated that, generally, plants were affected by both moderate and severe deficit irrigation levels. Deficit irrigation decreased shoot dry weight, root dry weight, leaf area index (LAI), relative water content (RWC), N, P, K, Ca, Fe, Zn, carotenoids, grain yield and its parameters, while root/shoot ratio, malondialdehyde (MDA), proline, soluble sugars, ascorbic acid, soluble phenols, peroxidase (POD), catalase (CAT), polyphenol oxidase (PPO), and ascorbate peroxidase (APX) were improved. The foliar applications of $\mathrm{K}_{2} \mathrm{SiO}_{3}$ relatively alleviated water stress-induced damage. In this respect, the treatment of $2 \mathrm{mM} \mathrm{K}_{2} \mathrm{SiO}_{3}$ was more effective than others and could be recommended to mitigate the effect of deficit irrigation on maize plants. Moreover, correlation analysis revealed a close link between yield and the most studied traits.
\end{abstract}

Keywords: drip irrigation; silicon; mineral nutrients; oxidative stress; osmolytes; yield; Zea mays 


\section{Introduction}

Semiarid regions are considered a pattern of drylands where the annual precipitation is not sufficient to meet the needs to grow vegetation all year. Generally, the rainfall in these regions ranges from 200 to $750 \mathrm{~mm} /$ year. This means the ratio between the total annual rainfall/the potential evapotranspiration reaches approximately 0.20 to 0.50 [1,2]. Currently, water scarcity is predicted to become the most severe environmental challenge that affects the agricultural sector and multiple socio-economic activities in many regions worldwide, especially with frequent climatic changes [3]. The harmful effects of drought stress on plants are usually associated with several events at cellular, biochemical, physiological and molecular levels that may enable the plants to adapt or tolerate such conditions [4-6]. These responses include the rapid generation of reactive oxygen species (ROS) [7], development of an array of complex antioxidant (nonenzymatic and enzymatic) systems [8], regulation of the expression of tolerance related genes [9] and alternation of nutrient uptake [10].

Maize (Zea mays) represents the third most important cereal crops cultivated worldwide after wheat and rice [11]. It has a high nutritional value for both human and animals; it contains approximately $72 \%$ starch, $10 \%$ protein and $4 \%$ fat, supplying an energy density of $365 \mathrm{Kcal} / 100 \mathrm{~g}$ [12]. Furthermore, maize provides suitable raw materials for several industries such as starch, fodder, silage and biofuels [13-15]. It is well documented that maize is highly sensitive to drought stress during any period of its growth cycle [16]. Water stress can cause considerable loss in the grain yield ranging from approximately $40-65 \%$ according to the genotype, stage of plant growth (the reproductive stage is more sensitive than the vegetative stage) and both the intensity and duration of exposure [17].

Potassium $(\mathrm{K})$ is an essential macronutrient with broad effects on higher plants. In maize, $\mathrm{K}$ alleviates the harmful effects of drought stress by different strategies, including the improvement of net carbon assimilation and phloem transport of sugars from leaves to roots [18]. Moreover, $\mathrm{K}$ can enhance leaf area, total yield, grain filling and water use efficiency (WUE) in the stressed plants by decreasing leaf evapotranspiration [19]. In addition, $\mathrm{K}$ could play a key role in preventing oxidative damage of the maize plants by maintaining ROS homeostasis and enhancing antioxidant capacity [20].

Although silicon ( $\mathrm{Si}$ ) is not considered an essential mineral nutrient, several lines of evidence confirmed its benefits for plants, particularly under biotic and abiotic stresses [21]. It can promote photosynthesis by increasing the concentration of chlorophyll [22], and affect the activities of RuBisCO and PEP-carboxylase that are required for $\mathrm{CO}_{2}$ fixation [23]. Furthermore, Si regulates antioxidant enzyme systems under diverse stress conditions [21]. Under drought stress, Si deposits in the cell walls of xylem vessels could prevent their compression caused by the high rate of transpiration [24], and it can improve the hydraulic conductivity of the roots in the radial direction leading to enhance uptake of water [25] and several essential nutrients [26]. Moreover, many previous reports indicated that Si could alleviate water deficit stress by improving osmotic adjustment and compatible solutes accumulation, i.e., proline, soluble sugars, free amino acids and polyamines, in several plant species $[25,27]$.

Potassium silicate $\left(\mathrm{K}_{2} \mathrm{SiO}_{3}\right)$ is a soluble source of potassium and silicon; it can be used as a fertilizer to maximize the benefits of both elements on plant growth and productivity. In this study, we provide insights into the underlying metabolic changes, uptake of mineral nutrients and some nonenzymatic and enzymatic antioxidants that may differ in maize plants as influenced by the foliar application of $\mathrm{K}_{2} \mathrm{SiO}_{3}$ under three irrigation regimes. These results may help to understand the link between the protective role of $\mathrm{K}_{2} \mathrm{SiO}_{3}$ against drought stress and the eventual yield of grains, especially under semiarid conditions.

\section{Materials and Methods}

\subsection{Experimental Layout and Growth Conditions}

Two field experiments were carried out during the seasons of 2018 and 2019 on a private farm, Ahmed Orabi Association, Cairo-Ismailia desert road, Qalyubia Governorate, Egypt. To investigate the effect of foliar application of potassium silicate $\left(\mathrm{K}_{2} \mathrm{SiO}_{3}\right)$ at 0,1 and $2 \mathrm{mM}$ on growth, yield and some physiological and biochemical attributes of maize plants grown under three different levels of 
drip irrigation (100, 75 and 50\% water requirements). Before the establishment of the experiments, samples of soil were collected by an Auger T-Handle at depth 30-60 cm for physical and chemical analyses (Table 1). Climatic data were recorded by an agrometeorological station, Ismailia, to monitor the environmental conditions during the experiment (Table 2).

Table 1. Physical and chemical analysis of the experimental soil before cultivation in the seasons of 2018 and 2019.

\begin{tabular}{|c|c|c|c|c|c|c|c|c|c|}
\hline \multirow{2}{*}{ Season } & \multirow{2}{*}{$\mathrm{pH}$} & \multirow{2}{*}{$\begin{array}{c}\mathrm{EC} \\
\mu \mathrm{S} \mathrm{\textrm {cm } ^ { - 1 }}\end{array}$} & \multirow{2}{*}{$\mathrm{CaCO}_{3} \%$} & \multicolumn{3}{|c|}{ Cation meq/L } & \multicolumn{3}{|c|}{ Anion meq/L } \\
\hline & & & & $\mathrm{Ca}^{++}$ & $\mathrm{Mg}^{++}$ & $\mathrm{Na}^{+}$ & $\mathrm{HCO}_{3}{ }^{-}$ & $\mathrm{CL}^{-}$ & $\mathrm{SO}_{4}^{--2}$ \\
\hline 2018 & 7.84 & 0.41 & 2.87 & 5.52 & 0.38 & 1.03 & 1.59 & 1.20 & 1.74 \\
\hline 2019 & 7.61 & 0.47 & 3.13 & 7.04 & 0.50 & 0.80 & 2.14 & 1.38 & 1.62 \\
\hline \multirow{2}{*}{$\mathrm{N}, \mathbf{P}, \mathrm{K}$} & $\mathbf{N}$ & $\mathbf{P}$ & K & \multirow{2}{*}{\multicolumn{2}{|c|}{ Sand $\%$}} & \multirow{2}{*}{ Silt $\%$} & \multirow{2}{*}{ Clay\% } & \multirow{2}{*}{\multicolumn{2}{|c|}{ Soil texture }} \\
\hline & \multicolumn{3}{|c|}{ (ppm) } & & & & & & \\
\hline 2018 & 2.88 & 6.38 & 1.17 & \multirow{2}{*}{\multicolumn{2}{|c|}{91.95}} & & \multirow{2}{*}{3.24} & \multirow{2}{*}{\multicolumn{2}{|c|}{ Sandy }} \\
\hline 2019 & 2.03 & 6.22 & 0.91 & & & 4.81 & & & \\
\hline
\end{tabular}

EC: Electrical conductivity.

Maize seeds of white single cross hybrid (Hytech 2030) produced by Misr Hytech Seed Int., Egypt was sown on 17th of May 2018 and 2019, respectively. The experiment was arranged in a split plot design with three replicates. A surface drip irrigation system with three levels (100, 75, and 50\% of water requirements) was implemented in the main plots, and the foliar applications of $\mathrm{K}_{2} \mathrm{SiO}_{3}$ treatments $(0,1$, and $2 \mathrm{mM})$ were randomly distributed in the subplots. The experimental unit area was $60 \mathrm{~m}^{2}$ ( $15 \mathrm{~m}$ length $\times 4 \mathrm{~m}$ width) consisting of 5 rows with $0.8 \mathrm{~m}$ distance between rows. The plant distance was $30 \mathrm{~cm}$ apart on one side. Maize plants were irrigated using drippers of $4 \mathrm{~L} \mathrm{~h}^{-1}$ capacity and $0.3 \mathrm{~m}$ distance between drippers. A flow meter was installed for each irrigation level treatment, and three rows were left without irrigation as a border between different irrigation levels.

Table 2. Monthly averages of solar radiation, precipitation, wind speed, air temperature and relative humidity during the period of cultivation (May-September) in the season 2018 and 2019.

\begin{tabular}{|c|c|c|c|c|c|c|c|c|}
\hline \multirow[t]{2}{*}{ Date } & \multirow{2}{*}{$\begin{array}{c}\begin{array}{c}\text { Solar } \\
\text { Radiation } \\
\text { Dgt }\left[\mathrm{MJ} / \mathrm{m}^{2}\right]\end{array} \\
\text { Average }\end{array}$} & \multirow{2}{*}{$\begin{array}{c}\text { Precipitation } \\
{[\mathrm{mm}]}\end{array}$} & \multicolumn{2}{|c|}{ Wind Speed $[\mathrm{m} / \mathrm{s}]$} & \multicolumn{3}{|c|}{ Air Temperature $\left[{ }^{\circ} \mathrm{C}\right]$} & \multirow{2}{*}{$\begin{array}{c}\text { Relative } \\
\text { Humidity [\%] } \\
\text { Average }\end{array}$} \\
\hline & & & Average & $\operatorname{Max}$ & Average & Min & Max & \\
\hline \multicolumn{9}{|c|}{2018} \\
\hline May & 671.29 & 0.0 & 1.4 & 8.9 & 23.9 & 11.8 & 38.5 & 62.5 \\
\hline June & 654.76 & 0.0 & 1.3 & 5.6 & 26.6 & 13.4 & 38.2 & 67.4 \\
\hline July & 616.47 & 0.0 & 0.9 & 4.8 & 27.7 & 16.9 & 37.4 & 75.5 \\
\hline August & 542.00 & 0.0 & 0.5 & 3.7 & 27.5 & 17.4 & 38.0 & 75.0 \\
\hline September & 424.92 & 0.0 & 0.7 & 3.8 & 25.2 & 14.7 & 36.2 & 73.5 \\
\hline \multicolumn{9}{|c|}{2019} \\
\hline May & 689.12 & 0.0 & 1.3 & 6.5 & 23.9 & 12.7 & 36.1 & 58.1 \\
\hline June & 535.47 & 0.0 & 1.3 & 5.2 & 27.6 & 15.7 & 39.6 & 65.6 \\
\hline July & 472.97 & 0.0 & 1.1 & 5.0 & 27.5 & 17.8 & 37.2 & 71.0 \\
\hline August & 415.72 & 0.0 & 1.0 & 4.6 & 27.3 & 17.0 & 37.5 & 73.4 \\
\hline September & 327.05 & 0.0 & 1.0 & 5.3 & 25.8 & 14.6 & 41.2 & 69.8 \\
\hline
\end{tabular}

\subsection{Calculations of Water Regimes}

Data of class A pan (Epan) for the experimental site expressed in $\mathrm{mm}$ /day were obtained from an agrometeorological station located close to the site. Water requirements (Table 3) for different irrigation levels were calculated for 105 days, and then irrigation was stopped for 11 days before the harvesting date (117 days after sowing). The calculation was made according to Doorenbos [28]. 
Table 3. Average amounts of the water requirements for the maize plants in the seasons of 2018 and 2019.

\begin{tabular}{|c|c|c|c|c|c|c|}
\hline \multirow[t]{2}{*}{ Days } & \multirow{2}{*}{ Date } & \multirow[t]{2}{*}{ Stage } & \multirow{2}{*}{$\mathrm{KC}^{*}$} & \multicolumn{3}{|c|}{$\begin{array}{l}\text { Irrigation Level } \\
\quad\left(\mathrm{m}^{3} \cdot \mathrm{ha}^{-1}\right)\end{array}$} \\
\hline & & & & $100 \%$ & $75 \%$ & $50 \%$ \\
\hline 10 days & $17 / 5: 26 / 5$ & \multirow{2}{*}{ initial } & 0.3 & 299.52 & 299.52 & 299.52 \\
\hline 10 days & $27 / 5: 5 / 6$ & & 0.6 & 694.08 & 694.08 & 694.08 \\
\hline \multicolumn{7}{|c|}{ Starting date of different irrigation regimes } \\
\hline 15 days & $6 / 6: 20 / 6$ & develonment & 0.9 & 953.28 & 714.96 & 476.64 \\
\hline 20 days & $21 / 6: 10 / 7$ & aeveropment & 1.0 & 1114.56 & 835.92 & 557.28 \\
\hline 20 days & $11 / 7: 30 / 7$ & & 1.2 & 1319.04 & 989.28 & 659.52 \\
\hline 20 days & $31 / 7: 19 / 8$ & Mid-season & 1.0 & 1085.76 & 814.32 & 542.88 \\
\hline 10 days & 20/8:29/8 & Last season & 0.9 & 1097.28 & 822.96 & 548.64 \\
\hline 11 days & $30 / 8: 11 / 9$ & & & \multicolumn{3}{|c|}{$\begin{array}{l}\text { Not irrigated before harvest } \\
\text { Total amount }\left(\mathrm{m}^{3} \mathrm{ha}^{-1}\right)\end{array}$} \\
\hline 116 Days & & & & 6563.52 & 5171.04 & 3778.56 \\
\hline
\end{tabular}

\subsection{Foliar Application and Sampling}

Maize plants were subjected to the foliar application of distilled water as a control and $\mathrm{K}_{2} \mathrm{SiO}_{3}$ ( 1 or $2 \mathrm{mM}$ ) four times: first at 24 days after sowing (DAS) then the subsequent applications were applied every 15 days. Tween 20 at $0.05 \mathrm{~mL} \mathrm{~L}^{-1}$ was used as a wetting agent for all foliar treatments ( $\mathrm{K}_{2} \mathrm{SiO}_{3}$-treated and control plants). To determine plant growth and physiological and biochemical changes in response to applications, plants samples were collected twice, first after 10 days of the last foliar application. Four plants were randomly collected from the inner rows to determine the vegetative growth (shoots and roots) in each experimental unit. Biochemical analyses were conducted using the 4th fully expanded leaf from the top, which was randomly collected from 3 plants of each experimental plot. In addition, two plants were randomly selected to collect the 4th fully expanded leaf from the top to determine mineral nutrients after drying in an oven at $105^{\circ} \mathrm{C}$. At the end of the experiment (117 DAS), grain yield per plant and its related traits were estimated, while the grain yield per hectare was determined from one inner row that was left for this purpose $\left(12 \mathrm{~m}^{2} /\right.$ experimental unit).

\subsection{Studied Parameters}

\subsubsection{Vegetative Growth}

Shoot and root dry weights were determined by drying four plants from each experimental unit in an air-forced ventilated oven at $105^{\circ} \mathrm{C}$. The dry weight ratio of root/shoot ratio was calculated. Leaf area index (LAI) was calculated as described by Iqbal and Hidayat [29].

\subsubsection{Leaf Relative Water Content (RWC)}

Leaf relative water content was determined according to Ünyayar et al. [30]. Leaf discs ( $1.8 \mathrm{~cm}$ diameter) from 10 fully expanded young leaves (ear leaf) were taken from 6-8 plants at the mid-canopy position before irrigation. Then the discs were weighed (FW) and placed immediately in distilled water for $2 \mathrm{~h}$ at $25^{\circ} \mathrm{C}$ then their turgid weights (TW) were recorded. The samples were dried in an oven at $110^{\circ} \mathrm{C}$ for $24 \mathrm{~h}(\mathrm{DW})$. Relative water content (RWC) was calculated using the following formula: $\mathrm{RWC}=(\mathrm{FW}-\mathrm{DW}) /(\mathrm{TW}-\mathrm{DW}) \times 100$.

\subsubsection{Membranes Lipid Peroxidation}

Lipid peroxidation was measured by the determination of malondialdehyde (MDA) as described by Heath and Packer [31]. Frozen leaf tissues were homogenized in $0.1 \%(w / v)$ trichloroacetic acid (TCA). 
The absorbance (A) of the supernatant was measured at $535 \mathrm{~nm}$ and corrected for nonspecific turbidity at $600 \mathrm{~nm}$ using a spectrophotometer (Chrom Tech CT-2200, Taiwan). The MDA concentration ( $\mathrm{nmol} \mathrm{g}^{-1} \mathrm{FW}$ ) was calculated using $\triangle \mathrm{OD}$ (A532-A600) and the extinction coefficient $\left(\varepsilon=155 \mathrm{mM}^{-1} \mathrm{~cm}^{-1}\right)$.

\subsubsection{Proline and Soluble Sugars}

Proline levels were determined using the method of acid-ninhydrin reagent as described by Bates et al. [32]. Soluble sugars were determined by anthrone-sulfuric acid reagent as described by Plummer [33].

\subsubsection{Determination of Mineral Nutrients}

Dry leaves were ground and digested using sulfuric acid and hydrogen peroxide. Leaf mineral concentrations of N, P, K, Ca, Fe and Zn were determined according to Cottenie et al. [34]. Nitrogen (N) was determined by the Kjeldahl method (Velp Scientifica, Europe). The colorimetric method by UV/VIS spectrophotometer was used to determine P; potassium (K) was determined by a Flamephotometer (Jenway, UK). Meanwhile, Ca, Fe and Zn were determined by atomic absorption spectrophotometry (AAS-Hitachi, Tokyo, Japan).

\subsubsection{Determination of Carotenoids, Ascorbic Acid and Total Soluble Phenols}

Carotenoids were determined using the acetone and petroleum ether method as described by de Carvalho et al. [35]. Ascorbic acid (AsA) was determined using the 2, 6-Dichloroindophenol titrimetric method according to Association of Official Analytical Chemists (A.O.A.C) [36]. Total soluble phenols were determined according to the method of Folin-Denis as described by Skalindi and Naczk [37].

\subsubsection{Quantification of Antioxidant Enzymes}

Leaf tissue of maize plants ( $0.5 \mathrm{~g}$ ) was homogenized in $4 \mathrm{~mL} 0.1 \mathrm{M} \mathrm{K}$-phosphate buffer ( $\mathrm{pH} 7.0)$ containing $1 \%(w / v)$ polyvinylpyrrolidone (PVP) and $0.1 \mathrm{mM}$ Ethylenediaminetetraacetic acid (EDTA). The homogenate was centrifuged at 10,000 rpm for $15 \mathrm{~min}$ and the supernatant was used as a crude enzyme extract. All the preparation steps of the enzyme extract were carried out at $0-4{ }^{\circ} \mathrm{C}$. Total soluble protein was determined according to Bradford [38].

Peroxidase (EC1.11.1.7) activity was quantified by the method of Hammerschmidt et al. [39]. The absorbance was recorded every $30 \mathrm{~s}$ for $3 \mathrm{~min}$ at $470 \mathrm{~nm}$ using a spectrophotometer (Chrom Tech CT-2200). Catalase (CAT) (EC 1.11.1.6) activity was determined according to the method of Cakmak et al. [40]. Polyphenol oxidase (PPO) (EC 1.14.18.1) activity was measured according to Oktay et al. [41]. The reaction mixture consisted of $100 \mu \mathrm{L}$ crude enzyme, $600 \mu \mathrm{L}$ catechol and $2.3 \mathrm{~mL}$ phosphate buffer $(0.1 \mathrm{M}, \mathrm{pH}$ 6.5). The absorbance at $420 \mathrm{~nm}$ was recorded at zero time and after $1 \mathrm{~min}$. Ascorbate peroxidase (APX) (EC 1.11.1.11) activity was measured according to the method of Nakano and Asada [42] by monitoring the decrease of absorbance at $290 \mathrm{~nm}$ following the ascorbate oxidation for $3 \mathrm{~min}$. The reaction was initiated by the addition of $\mathrm{H}_{2} \mathrm{O}_{2}$. All enzyme activities were expressed as $\Delta \mathrm{OD} \mathrm{min}^{-1} \mathrm{mg}^{-1}$ protein.

\subsubsection{Determination of Yield Parameters}

Maize ears were harvested at 117 DAS and averages of ear length, ear diameter, number of grains.ear ${ }^{-1}$, weight of grains.ear ${ }^{-1}$, weight of grains plant $^{-1}$ were estimated from 10 random plants per each experimental unit. Eventually, total grain yield $\left(\mathrm{t} \mathrm{ha}^{-1}\right)$ was calculated using the average yield of grains $/ 12 \mathrm{~m}^{2}$ (one inner row was left for this purpose in each experimental unit).

\subsubsection{Statistical Analysis}

Data of the two seasons were subjected to combined analysis following the two way ANOVA procedure as described by Snedecor and Cochran [43] using MSTAT-C software (Michigan State University, USA). Duncan's test based on a probability of $p \leq 0.05$ was used to determine the significant differences between means. 
All data were expressed as means \pm standard deviation (SD). The correlation coefficient between the grain yield $\left(\mathrm{t} \mathrm{ha}^{-1}\right)$ and different physiological and biochemical aspects was also estimated.

\section{Results}

\subsection{The Main Effects of the Irrigation Levels and $\mathrm{K}_{2} \mathrm{SiO}_{3}$ Foliar Applications}

Reduction of irrigation (moderate or severe level) caused significant $(p \leq 0.05)$ decreases in shoot dry weight and root dry weight. Furthermore, a substantial reduction in the LAI, RWC, N, P, K, $\mathrm{Ca}, \mathrm{Fe}$, carotenoids, ear length, ear diameter, number of grains/ear, weight of grains/plant and grain yield (ton/ha) was observed when compared to the well-irrigated plants (Table 4), while, Zn was only decreased when plants were exposed to the irrigation level of $50 \%$ WR. In contrast, root/shoot ratio, MDA, proline, soluble sugars, ascorbic acid and soluble phenols, as well as the activities of peroxidase (POD), catalase (CAT), polyphenol oxidase (PPO), and ascorbate peroxidase (APX) were significantly increased (Table 4). The foliar applications of $\mathrm{K}_{2} \mathrm{SiO}_{3}$ at 1 or $2 \mathrm{mM}$ significantly increased all studied variables except root/shoot ratio, MDA, proline and $\mathrm{Zn}$. The treatment of $2 \mathrm{mM} \mathrm{K}_{2} \mathrm{SiO}_{3}$ was more effective in enhancing yield and its parameters than the lower concentration $(1 \mathrm{mM})$.

Table 4. Mean comparison shows the main effects of the irrigation levels (100, 75, and $50 \%$ of water requirements) and the foliar applications of $\mathrm{K}_{2} \mathrm{SiO}_{3}(0,1$, and $2 \mathrm{mM}) . \mathrm{KSi} 0: \mathrm{K}_{2} \mathrm{SiO}_{3}$-untreated plants, KSi 1: $\mathrm{K}_{2} \mathrm{SiO}_{3}(1 \mathrm{mM})$ and $\mathrm{KSi} 2: \mathrm{K}_{2} \mathrm{SiO}_{3}(2 \mathrm{mM})$. On the vegetative growth, water status, lipid peroxidation, osmolytes, mineral nutrients, non-enzymatic antioxidants, antioxidant enzymes, yield and its parameters of maize plants.

\begin{tabular}{|c|c|c|c|c|c|c|}
\hline \multirow{2}{*}{ Variables } & \multicolumn{3}{|c|}{ Irrigation Level } & \multicolumn{3}{|c|}{ Foliar Application } \\
\hline & $100 \%$ & $75 \%$ & $50 \%$ & KSi 0 & KSi 1 & KSi 2 \\
\hline Shoot dry weight (g.plant ${ }^{-1}$ ) & $318.4^{\mathrm{A}}$ & $242.1^{\text {B }}$ & $208.1^{C}$ & $232.6^{\mathrm{C}}$ & $260.3^{B}$ & $275.7^{\mathrm{A}}$ \\
\hline Root dry weight (g.plant ${ }^{-1}$ ) & $45.32^{\mathrm{A}}$ & $38.20^{\mathrm{B}}$ & $33.01^{C}$ & $36.52^{\mathrm{B}}$ & $39.43^{\mathrm{A}}$ & $40.58^{\mathrm{A}}$ \\
\hline Root/shoot ratio & $0.144^{\mathrm{B}}$ & $0.158^{\mathrm{A}}$ & $0.159^{\mathrm{A}}$ & $0.157^{\mathrm{A}}$ & $0.153^{\mathrm{A}}$ & $0.150^{\mathrm{A}}$ \\
\hline LAI & $7.15^{\mathrm{A}}$ & $5.19^{\mathrm{B}}$ & $4.08^{\mathrm{C}}$ & $4.62^{\mathrm{C}}$ & $5.44^{\mathrm{B}}$ & $6.35^{\mathrm{A}}$ \\
\hline RWC (\%) & $88.11^{\mathrm{A}}$ & $73.13^{\text {B }}$ & $67.79^{C}$ & $75.52^{\text {B }}$ & $77.17^{\mathrm{A}}$ & $76.34 \mathrm{AB}$ \\
\hline MDA (nmol.g $\left.{ }^{-1} \mathrm{FW}\right)$ & $5.82^{\mathrm{C}}$ & $11.99^{\mathrm{B}}$ & $13.62^{\mathrm{A}}$ & $11.08^{\mathrm{A}}$ & $10.27^{\text {B }}$ & $10.09^{\mathrm{B}}$ \\
\hline Proline ( $\left.\mu \mathrm{g} \cdot \mathrm{g}^{-1} \mathrm{FW}\right)$ & $183.3^{\mathrm{C}}$ & $314.0^{\mathrm{A}}$ & $241.6^{\text {B }}$ & $285.0^{\mathrm{A}}$ & $241.5^{\text {B }}$ & $212.2^{C}$ \\
\hline Soluble sugars (mg. $\left.{ }^{-1} \mathrm{DW}\right)$ & $24.50^{\text {B }}$ & $45.54^{\mathrm{A}}$ & $44.53^{\mathrm{A}}$ & $35.13^{C}$ & $37.99^{\text {B }}$ & $41.44^{\mathrm{A}}$ \\
\hline $\mathrm{N}\left(\mathrm{mg} \cdot \mathrm{g}^{-1} \mathrm{DW}\right)$ & $85.29^{\mathrm{A}}$ & $71.00^{\mathrm{B}}$ & $62.14^{C}$ & $70.39^{\mathrm{B}}$ & $71.31^{\mathrm{B}}$ & $76.72^{\mathrm{A}}$ \\
\hline P (mg.g ${ }^{-1}$ DW) & $2.24^{\mathrm{A}}$ & $1.91^{\mathrm{B}}$ & $1.50^{\mathrm{C}}$ & $1.77^{\mathrm{B}}$ & $1.93^{\mathrm{A}}$ & $1.96^{\mathrm{A}}$ \\
\hline $\mathrm{K}\left(\mathrm{mg}^{-} \mathrm{g}^{-1} \mathrm{DW}\right)$ & $11.74^{\mathrm{A}}$ & $9.90^{\mathrm{B}}$ & $8.81^{C}$ & $8.02^{C}$ & $10.65^{\text {В }}$ & $11.79 \mathrm{~A}$ \\
\hline $\mathrm{Ca}\left(\mathrm{mg}^{-g^{-1}} \mathrm{DW}\right)$ & $7.25^{\mathrm{A}}$ & $6.52^{\mathrm{B}}$ & $5.22^{C}$ & $6.07^{\mathrm{B}}$ & $6.31 \mathrm{AB}$ & $6.61^{\mathrm{A}}$ \\
\hline $\mathrm{Fe}\left(\mu \mathrm{g} \cdot \mathrm{g}^{-1} \mathrm{DW}\right)$ & $203.9^{\mathrm{A}}$ & $180.5^{\mathrm{B}}$ & $161.7^{\mathrm{C}}$ & $169.7^{C}$ & $180.7^{\mathrm{B}}$ & $195.6^{\mathrm{A}}$ \\
\hline $\mathrm{Zn}\left(\mu \mathrm{g} \cdot \mathrm{g}^{-1} \mathrm{DW}\right)$ & $46.3^{\mathrm{A}}$ & $47.0^{\mathrm{A}}$ & $41.0^{\mathrm{B}}$ & $48.6^{\mathrm{A}}$ & $42.9^{\mathrm{B}}$ & $42.8^{\mathrm{B}}$ \\
\hline Carotenoids $\left(\mathrm{mg}^{\left.-\mathrm{g}^{-1} \mathrm{FW}\right)}\right.$ & $0.332^{\mathrm{A}}$ & $0.308^{\mathrm{B}}$ & $0.288^{C}$ & $0.277^{\mathrm{C}}$ & $0.317^{\mathrm{B}}$ & $0.334^{\mathrm{A}}$ \\
\hline Ascorbic acid $\left(\mu \mathrm{mol} . \mathrm{g}^{-1} \mathrm{FW}\right)$ & $1.36^{\mathrm{C}}$ & $1.78^{\mathrm{A}}$ & $1.67^{\mathrm{B}}$ & $1.57^{\mathrm{B}}$ & $1.61 \mathrm{AB}$ & $1.64^{\mathrm{A}}$ \\
\hline Soluble phenols $\left(\mu \mathrm{g} \cdot \mathrm{g}^{-1} \mathrm{FW}\right)$ & $13.97^{C}$ & $16.39^{\text {B }}$ & $17.29 \mathrm{~A}$ & $15.27^{\mathrm{C}}$ & $15.87^{\text {B }}$ & $16.49^{\mathrm{A}}$ \\
\hline POD $\left(\Delta\right.$ O.D. $\min ^{-1} . \mathrm{mg}$ protein $)$ & $14.3^{\mathrm{C}}$ & $33.6^{\mathrm{B}}$ & $35.6^{\mathrm{A}}$ & $25.92^{\text {B }}$ & $28.90^{\mathrm{A}}$ & $28.67^{\mathrm{A}}$ \\
\hline CAT ( $\Delta$ O.D. $\mathrm{min}^{-1} . \mathrm{mg}$ protein) & $2.64^{\mathrm{C}}$ & $4.17^{\mathrm{A}}$ & $3.57^{\mathrm{B}}$ & $3.19^{\mathrm{B}}$ & $3.58^{\mathrm{A}}$ & $3.60^{\mathrm{A}}$ \\
\hline $\mathrm{PPO}\left(\Delta\right.$ O.D. $\mathrm{min}^{-1} . \mathrm{mg}$ protein $)$ & $6.95^{\mathrm{C}}$ & $8.59^{\mathrm{B}}$ & $9.69^{\mathrm{A}}$ & $7.97^{\mathrm{B}}$ & $8.57^{\mathrm{A}}$ & $8.67^{\mathrm{A}}$ \\
\hline APX $\left(\triangle\right.$ O.D. $\min ^{-1} . \mathrm{mg}$ protein $)$ & $2.83^{\mathrm{C}}$ & $4.36^{\mathrm{A}}$ & $4.01^{\text {B }}$ & $3.40^{\mathrm{B}}$ & $3.85^{\mathrm{A}}$ & $3.94^{\mathrm{A}}$ \\
\hline Ear length $(\mathrm{cm})$ & $23.3^{\mathrm{A}}$ & $19.1^{\mathrm{B}}$ & $15.7^{\mathrm{C}}$ & $18.2^{\mathrm{C}}$ & $19.4^{\mathrm{B}}$ & $20.5^{\mathrm{A}}$ \\
\hline Ear diameter $(\mathrm{cm})$ & $4.7^{\mathrm{A}}$ & $4.4^{\mathrm{B}}$ & $3.3^{C}$ & $4.00^{\mathrm{C}}$ & $4.17^{\mathrm{B}}$ & $4.30^{\mathrm{A}}$ \\
\hline Number of grains/ear & $332.4^{\mathrm{A}}$ & $271.8^{\text {B }}$ & $226.3^{C}$ & $264.7^{\text {B }}$ & $281.2^{\mathrm{A}}$ & $284.6^{\mathrm{A}}$ \\
\hline Weight of grains/ear $(\mathrm{g})$ & $109.7^{\mathrm{A}}$ & $84.5^{\mathrm{B}}$ & $66.2^{\mathrm{C}}$ & $79.5^{\mathrm{C}}$ & $88.8^{\mathrm{B}}$ & $92.2^{\mathrm{A}}$ \\
\hline Weight of grains/plant (g) & $172.8^{\mathrm{A}}$ & $127.6^{\mathrm{B}}$ & $95.0^{\mathrm{C}}$ & $118.1^{\mathrm{C}}$ & $135.0^{\mathrm{B}}$ & $142.4^{\mathrm{A}}$ \\
\hline Grain yield (ton $\left.\cdot h^{-1}\right)$ & $7.94^{\mathrm{A}}$ & $5.82^{\mathrm{B}}$ & $4.39^{\mathrm{C}}$ & $5.33^{\mathrm{C}}$ & $6.14^{\mathrm{B}}$ & $6.68^{\mathrm{A}}$ \\
\hline
\end{tabular}

Data of the two seasons of 2018 and 2019 were subjected to combined analysis with 3 replicates in each season. The different superscript capital letters within a row indicate significantly different values according to Duncan's multiple range tests $(p<0.05)$. LAI, leaf area index; RWC, relative water content; MDA, malondialdehyde; POD, peroxidase; $\mathrm{CAT}$, catalase; $\mathrm{PPO}$, polyphenol oxidase; $\mathrm{APX}$, ascorpate peroxidase. 


\subsection{Changes in Plant Growth}

The progressive reduction in the irrigation level significantly $(p \leq 0.05)$ inhibited plant growth in terms of shoot dry weight, root dry weight and LAI. In contrast, root/shoot ratio was not affected compared to the well-irrigated control (Figure 1). When plants were treated with $\mathrm{K}_{2} \mathrm{SiO}_{3}$ (1 or $2 \mathrm{mM}$ ), a significant increase was observed in shoot dry weight and LAI either under nonstressed or stressed conditions. Meanwhile, this trend was just obvious in root dry weight under water shortage conditions. Root/shoot ratio revealed a significant decrease in the $\mathrm{K}_{2} \mathrm{SiO}_{3}$-treated plants under well-irrigated conditions. Generally, the highest concentration of the $\mathrm{K}_{2} \mathrm{SiO}_{3}$ treatments $(2 \mathrm{mM})$ was more effective in this respect (Figure 1).

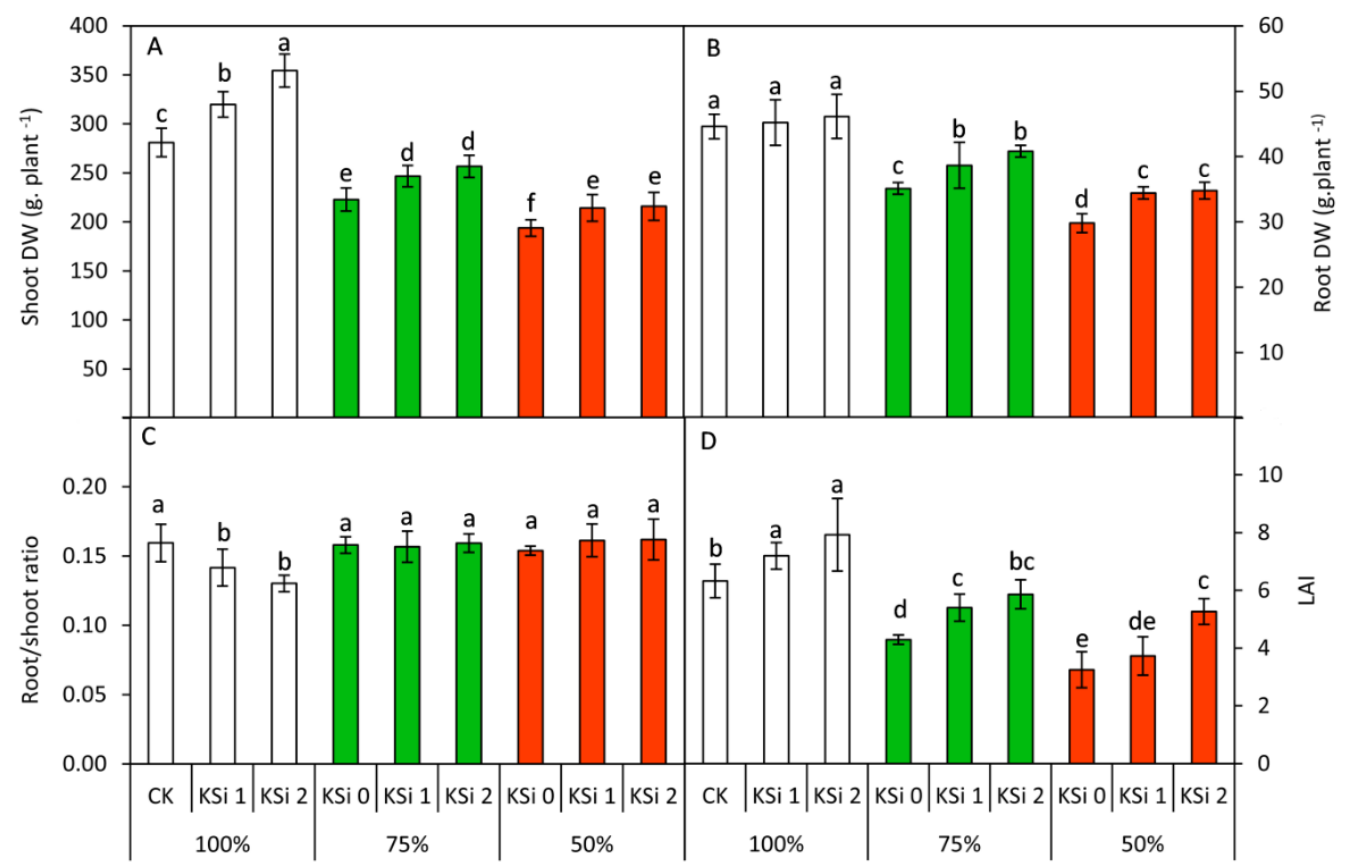

Figure 1. Shoot dry weight (A), root dry weight (B), root/shoot ratio (C) and leaf area index (LAI) (D) of the maize plants at 80 days after sowing (DAS) as influenced by the foliar application of $\mathrm{K}_{2} \mathrm{SiO}_{3}$ $(0,1$ and $2 \mathrm{mM}$ ) under three irrigation regimes: 100\% (white), $75 \%$ (green) and 50\% (orange) of water requirements. CK: well-watered control, $\mathrm{KSi} 0: \mathrm{K}_{2} \mathrm{SiO}_{3}$-untreated plants, $\mathrm{KSi} 1: \mathrm{K}_{2} \mathrm{SiO}_{3}(1 \mathrm{mM})$ and $\mathrm{KSi}$ 2: $\mathrm{K}_{2} \mathrm{SiO}_{3}(2 \mathrm{mM})$. Data of the two seasons of 2018 and 2019 were subjected to combined analysis. Means were presented \pm SD. Different letters are significant differences, according to Duncan's multiple range tests $(p<0.05)$.

\subsection{Changes in RWC, MDA, Proline and Soluble Sugars}

Plants that were exposed to deficit irrigation demonstrated a significant $(p \leq 0.05)$ increase in MDA, proline and soluble sugars, whereas RWC was diminished compared to the well-irrigated conditions (Figure 2). The foliar applications of $\mathrm{K}_{2} \mathrm{SiO}_{3}$ significantly enhanced RWC under both investigated deficit-irrigation levels, while this tendency was conspicuous in soluble sugars under moderate level of deficit irrigation. Conversely, MDA and proline generally exhibited a significant decrease in $\mathrm{K}_{2} \mathrm{SiO}_{3}$-treated plants compared to the untreated ones under stressed conditions. Overall, the treatment of $2 \mathrm{mM} \mathrm{K}_{2} \mathrm{SiO}_{3}$ was more efficient than the other treatments. 


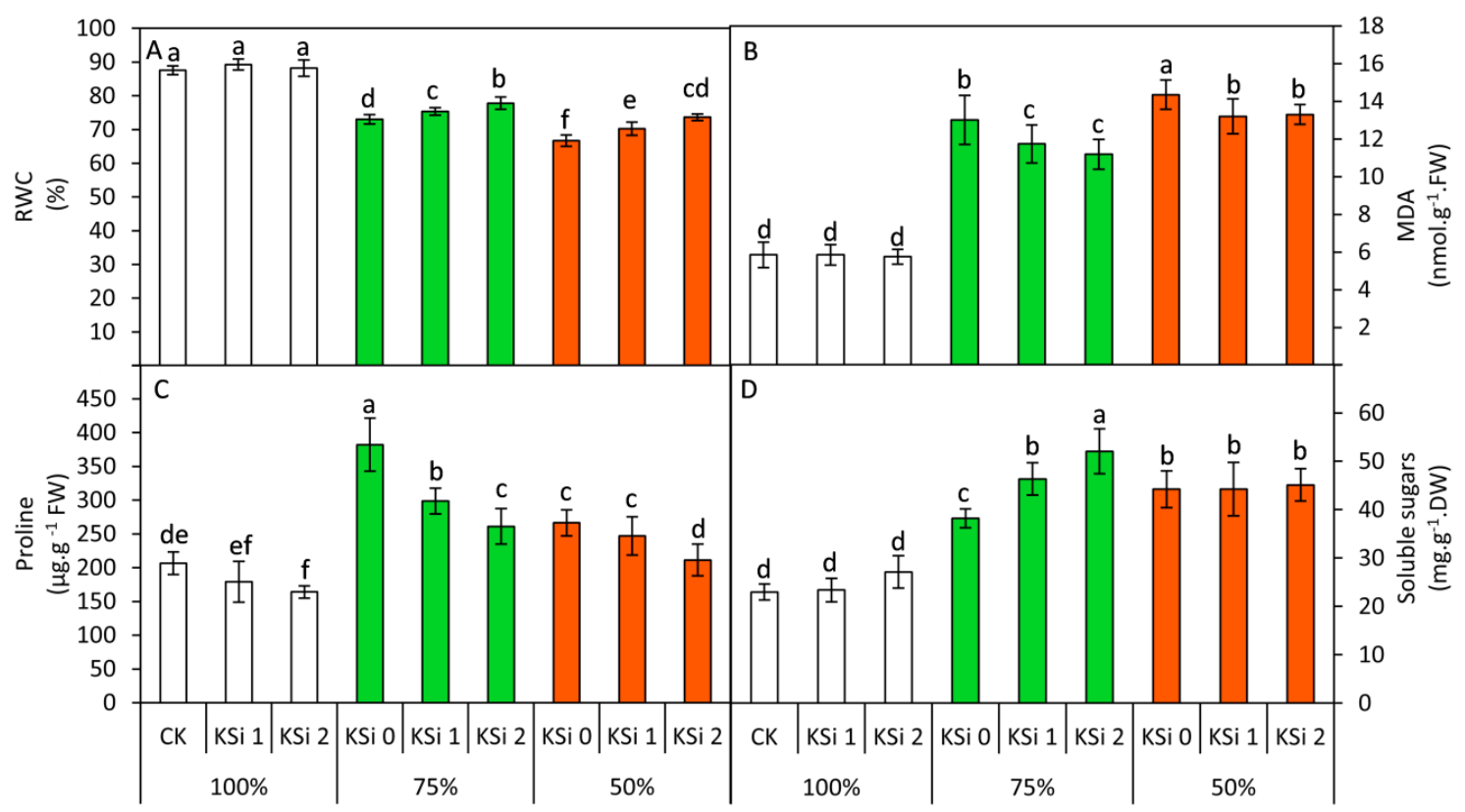

Figure 2. Leaf relative water content (RWC) (A), membranes lipid peroxidation as indicated by malondialdehyde (MDA) (B), proline (C) and soluble sugars (D) of $t$ maize plants at 80 DAS as influenced by the foliar application of $\mathrm{K}_{2} \mathrm{SiO}_{3}(0,1$ and $2 \mathrm{mM})$ under three irrigation regimes: $100 \%$ (white), 75\% (green) and 50\% (orange) of water requirements. CK: well-watered control, KSi 0: $\mathrm{K}_{2} \mathrm{SheiO}_{3}$-untreated plants, $\mathrm{KSi} 1: \mathrm{K}_{2} \mathrm{SiO}_{3}(1 \mathrm{mM})$ and $\mathrm{KSi} 2: \mathrm{K}_{2} \mathrm{SiO}_{3}(2 \mathrm{mM})$. Data of the two seasons of 2018 and 2019 were subjected to combined analysis. Means were presented \pm SD. Different letters are significant differences, according to Duncan's multiple range tests $(p<0.05)$.

\subsection{Changes in Mineral Nutrients}

To evaluate the nutritional status of plants under continuous deficit irrigation and $\mathrm{K}_{2} \mathrm{SiO}_{3}$ foliar applications, N, P, K, Ca, Fe and Zn were quantified (Figure 3). The general tendency was that deficit irrigation obviously and significantly $(p \leq 0.05)$ decreased $\mathrm{N}, \mathrm{K}, \mathrm{Ca}$ and $\mathrm{Fe}$ in $\mathrm{K}_{2} \mathrm{SiO}_{3}$ nontreated plants under both examined deficit levels of irrigation (75\% and 50\%). In comparison, $\mathrm{P}$ and $\mathrm{Zn}$ were only affected under the severe level of deficit irrigation (50\%). Applied $\mathrm{K}_{2} \mathrm{SiO}_{3}$, specifically at $2 \mathrm{mM}$, significantly improved the concentration of N, P, K, Ca and Fe under unstressed conditions. In contrast, a significant reduction in $\mathrm{Zn}$ was manifested in $\mathrm{K}_{2} \mathrm{SiO}_{3}$-treated plants under well-irrigated conditions. When plants were subjected to continuous deficit irrigation, the treatment of $2 \mathrm{mM} \mathrm{K}_{2} \mathrm{SiO}_{3}$ exhibited the highest significant increases in N, K and Fe under both investigated levels of deficit irrigation. A similar trend was only observed in $\mathrm{P}$ under a moderate level of irrigation.

On the other hand, no significant differences were detected in $\mathrm{Ca}$ between $\mathrm{K}_{2} \mathrm{SiO}_{3}$ nontreated and the treated plants under both deficit irrigation levels (75\% and 50\%). Meanwhile, $\mathrm{Zn}$ was significantly decreased by the treatments of $\mathrm{K}_{2} \mathrm{SiO}_{3}$ under the moderate level of irrigation. This effect did not occur under the lower level of irrigation (50\%). 


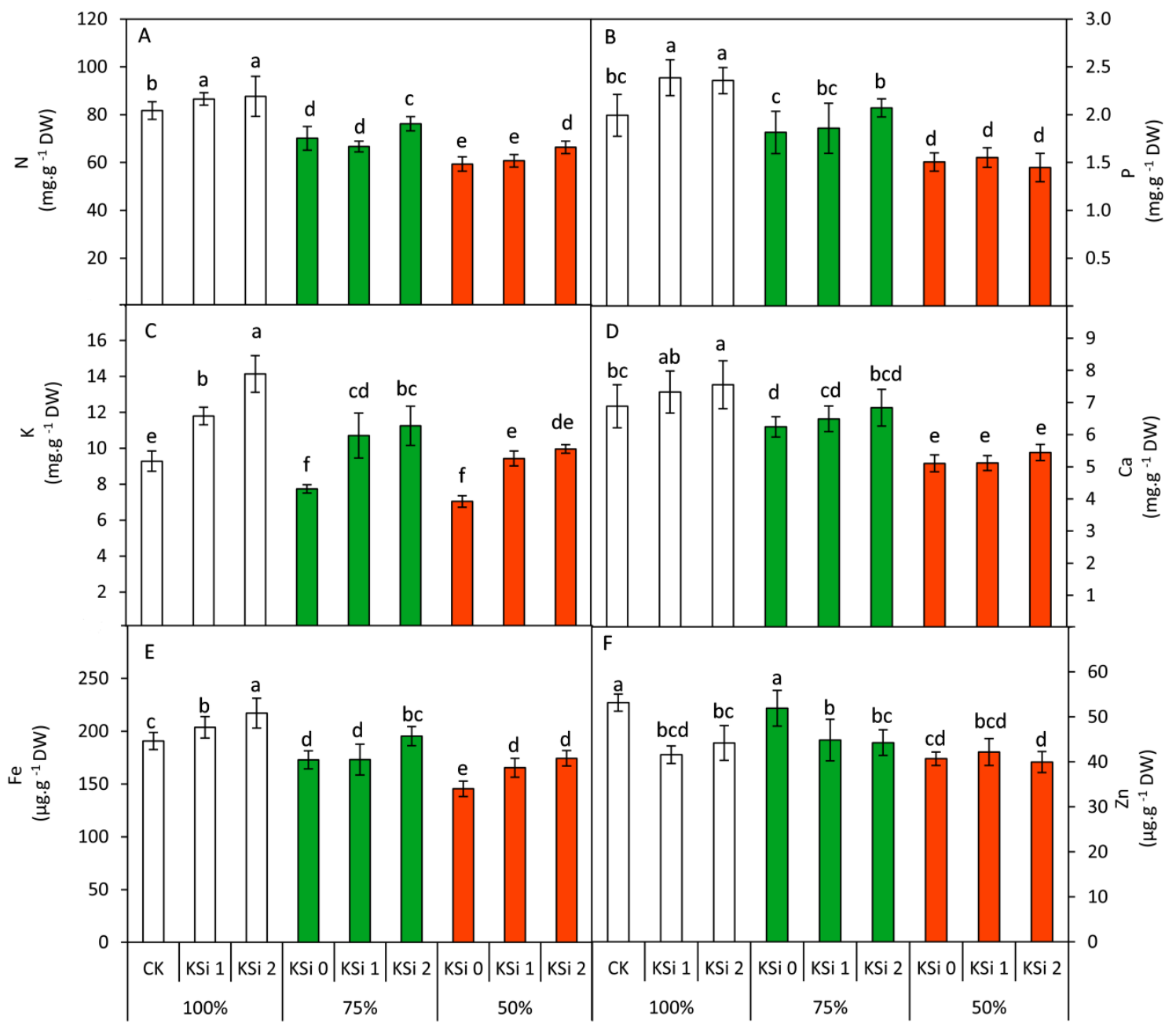

Figure 3. Leaf mineral content including $\mathrm{N}(\mathbf{A}), \mathrm{P}(\mathbf{B}), \mathrm{K}(\mathrm{C}) \mathrm{Ca}(\mathrm{D}), \mathrm{Fe}(\mathrm{E})$ and $\mathrm{Zn}(\mathrm{F})$ of the maize plants at $80 \mathrm{DAS}$ as influenced by the foliar application of $\mathrm{K}_{2} \mathrm{SiO}_{3}(0,1$ and $2 \mathrm{mM})$ under three irrigation regimes: $100 \%$ (white), $75 \%$ (green) and 50\% (orange) of water requirements. CK: well-watered control, KSi 0: $\mathrm{K}_{2} \mathrm{SiO}_{3}$-untreated plants, $\mathrm{KSi} 1: \mathrm{K}_{2} \mathrm{SiO}_{3}(1 \mathrm{mM})$ and $\mathrm{KSi} 2: \mathrm{K}_{2} \mathrm{SiO}_{3}(2 \mathrm{mM})$. Data of the two seasons of 2018 and 2019 were subjected to combined analysis. Means were presented \pm SD. Different letters are significant differences, according to Duncan's multiple range tests $(p<0.05)$.

\subsection{Changes in Nonenzymatic Antioxidants}

Nonenzymatic antioxidant capacity of plants was investigated by the determination of carotenoids, ascorbic acid and soluble phenols (Figure 4). Plants that were not applied by $\mathrm{K}_{2} \mathrm{SiO}_{3}$ and exposed to continuous deficit irrigation demonstrated a significant $(p \leq 0.05)$ increase in ascorbic acid and soluble phenols compared to the well-watered conditions, whereas carotenoids did not show any significant differences in this respect. Applied $\mathrm{K}_{2} \mathrm{SiO}_{3}(1$ or $2 \mathrm{mM})$ significantly enhanced carotenoids and ascorbic acid, while soluble phenols were not changed under well-irrigated conditions. Similarly, $\mathrm{K}_{2} \mathrm{SiO}_{3}$ applications, in particular at the highest concentration $(2 \mathrm{mM})$, exhibited the highest significant increases in carotenoids and soluble phenols under both investigated levels of deficit irrigation (75 and 50\%). On the other hand, ascorbic acid revealed an opposite trend by the treatment of $2 \mathrm{mM}$ $\mathrm{K}_{2} \mathrm{SiO}_{3}$ under the moderate (75\%) and lower (50\%) levels of irrigation. 


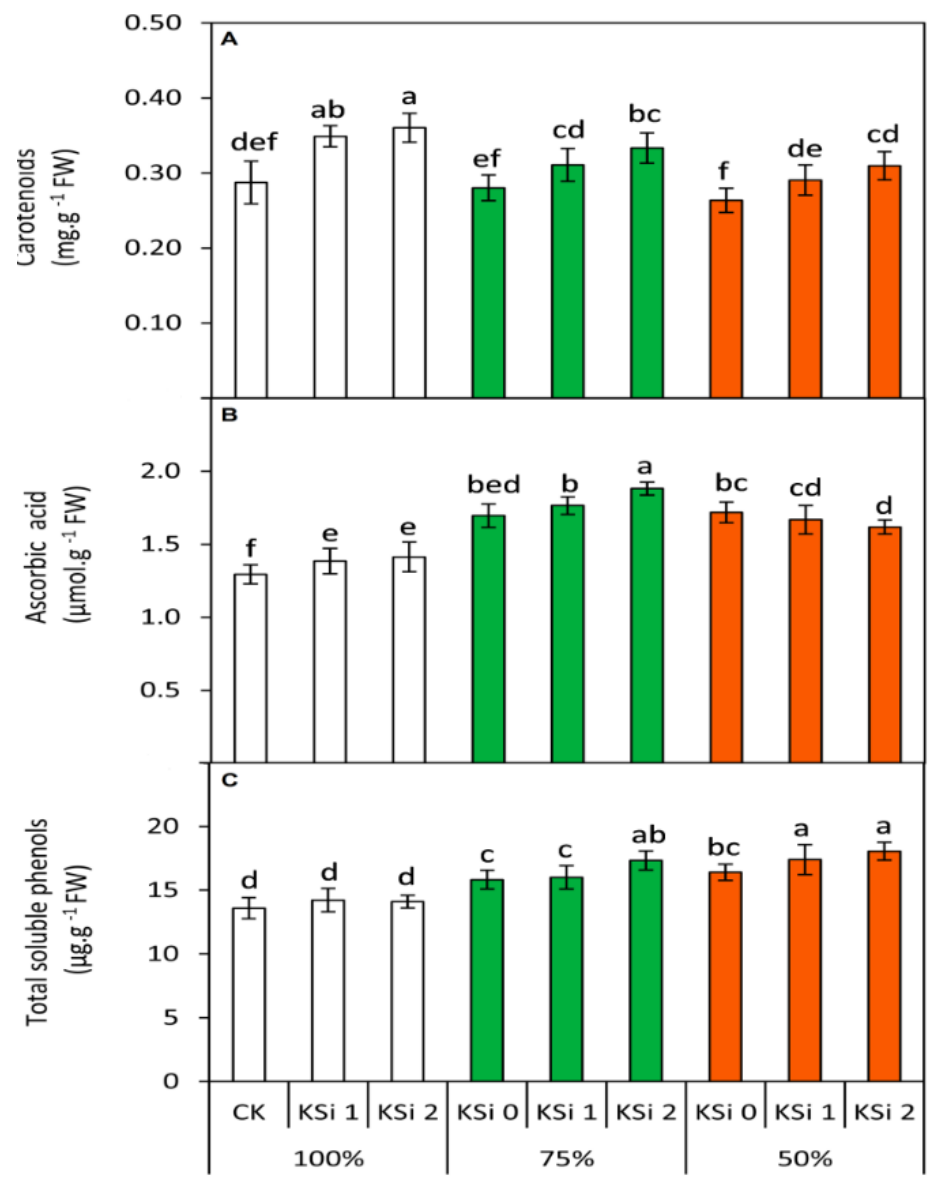

Figure 4. Nonenzymatic antioxidants including carotenoids (A), ascorbic acid (AsA) (B) and total soluble phenols $(\mathrm{C})$ in the leaves of the maize plants at $80 \mathrm{DAS}$ as influenced by the foliar application of $\mathrm{K}_{2} \mathrm{SiO}_{3}(0,1$ and $2 \mathrm{mM}$ ) under three irrigation regimes: $100 \%$ (white), $75 \%$ (green) and $50 \%$ (orange) of water requirements. $\mathrm{CK}$ : well-watered control, $\mathrm{KSi}$ 0: $\mathrm{K}_{2} \mathrm{SiO}_{3}$-untreated plants, $\mathrm{KSi} 1: \mathrm{K}_{2} \mathrm{SiO}_{3}(1 \mathrm{mM})$ and $\mathrm{KSi} 2: \mathrm{K}_{2} \mathrm{SiO}_{3}(2 \mathrm{mM})$. Data of the two seasons of 2018 and 2019 were subjected to combined analysis. Means were presented \pm SD. Different letters are significant differences, according to Duncan's multiple range tests $(p<0.05)$.

\subsection{Changes in Antioxidant Enzymes}

The activities of antioxidant enzymes (POD, CAT, PPO, and APX) were determined in this study under deficit irrigation conditions and the exogenous application of $\mathrm{K}_{2} \mathrm{SiO}_{3}$ (Figure 5). No significant differences were observed between $\mathrm{K}_{2} \mathrm{SiO}_{3}$-treated, and nontreated plants in the activity of all studied antioxidant enzymes under well-irrigated conditions. Reducing irrigation levels significantly $(p \leq 0.05)$ increased the activity of these enzymes compared to the well-irrigated conditions. Applied- $\mathrm{K}_{2} \mathrm{SiO}_{3}$ significantly enhanced the activity of CAT, PPO and APX under the moderate level of irrigation $(75 \%)$, whereas POD was not affected. When plants were exposed to severe deficit irrigation $(50 \%)$, POD exhibited a significant increase by the treatment of $1 \mathrm{mM} \mathrm{K}_{2} \mathrm{SiO}_{3}$. At the same time, the highest activity of CAT and PPO were obtained by the treatment of $2 \mathrm{mM} \mathrm{K}_{2} \mathrm{SiO}_{3}$. On the contrary, APX did not reveal any significant differences between $\mathrm{K}_{2} \mathrm{SiO}_{3}$-treated and nontreated plants under the lower level of irrigation. 


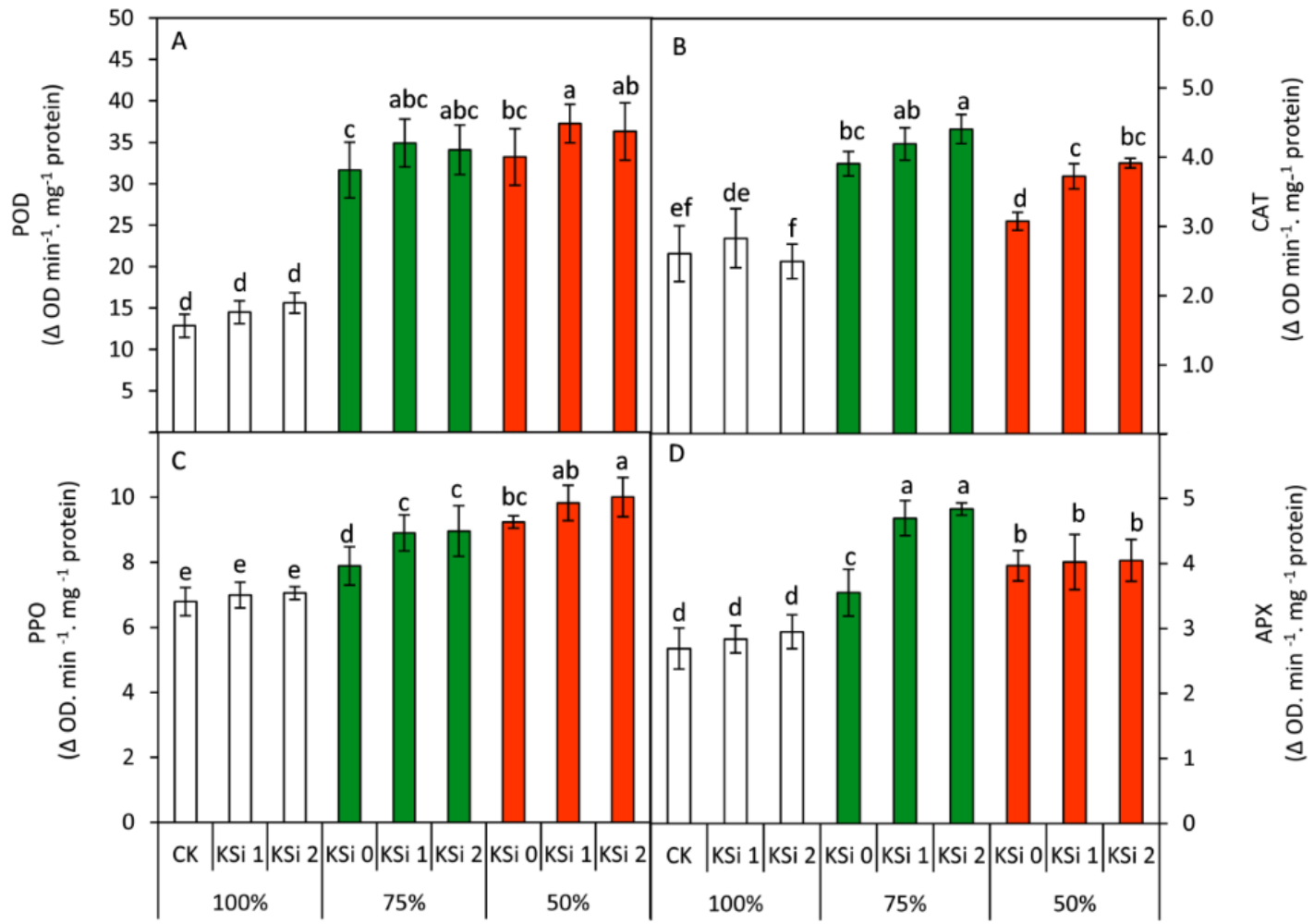

Figure 5. Activities of antioxidant enzymes including POD (A), CAT (B), PPO (C) and APX (D) in the leaves of maize plants at $80 \mathrm{DAS}$ as influenced by the foliar application of $\mathrm{K}_{2} \mathrm{SiO}_{3}(0,1$ and $2 \mathrm{mM})$ under three irrigation regimes: $100 \%$ (white), $75 \%$ (green) and $50 \%$ (orange) of water requirements. CK: well-watered control, $\mathrm{KSi} 0: \mathrm{K}_{2} \mathrm{SiO}_{3}$-untreated plants, $\mathrm{KSi} 1: \mathrm{K}_{2} \mathrm{SiO}_{3}(1 \mathrm{mM})$ and $\mathrm{KSi} 2: \mathrm{K}_{2} \mathrm{SiO}_{3}(2 \mathrm{mM})$. Data of the two seasons of 2018 and 2019 were subjected to combined analysis. Means were presented \pm SD. Different letters are significant differences, according to Duncan's multiple range tests $(p<0.05)$.

\subsection{Changes in Yield Parameters}

Grain yield and its parameters, including ear length, ear diameter, number of grains.ear ${ }^{-1}$, weight of grains ear ${ }^{-1}$, weight of grains. plant ${ }^{-1}$ and total grain yield $\left(\mathrm{tha}^{-1}\right)$ were estimated in this investigation (Figure 6). Concerning $\mathrm{K}_{2} \mathrm{SiO}_{3}$-untreated plants, reducing irrigation level led to significant $(p \leq 0.05)$, and gradual decreases in all yield parameters studied in parallel with the severity of deficit irrigation. Generally, except for the number of grains.ear ${ }^{-1}$ under the lower level of irrigation, applied- $\mathrm{K}_{2} \mathrm{SiO}_{3}$, specifically at $2 \mathrm{mM}$, significantly improved all studied traits regardless of the level of irrigation.

\subsection{Relationships between Grain Yield and RWC, MDA, Osmolytes, Nutrients and Antioxidants}

To elucidate the relationships between the grain yield of maize plants as influenced by the foliar applications of $\mathrm{K}_{2} \mathrm{SiO}_{3}$ under different irrigation regimes and RWC, MDA, osmolytes, nutrients and antioxidants, the correlation coefficient was analyzed (Figure 7). We observed that grain yield ( $\left.\mathrm{t} \mathrm{ha}^{-1}\right)$ was significantly and positively correlated with leaf relative water content (RWC), carotenoids, N, P, K, $\mathrm{Ca}$ and Fe. Meanwhile, MDA, soluble sugars, soluble phenols, POD and PPO demonstrated a negative correlation. On the other hand, proline, ascorbic acid (AsA), CAT, APX and Zn did not reveal any significant correlation in this respect. 


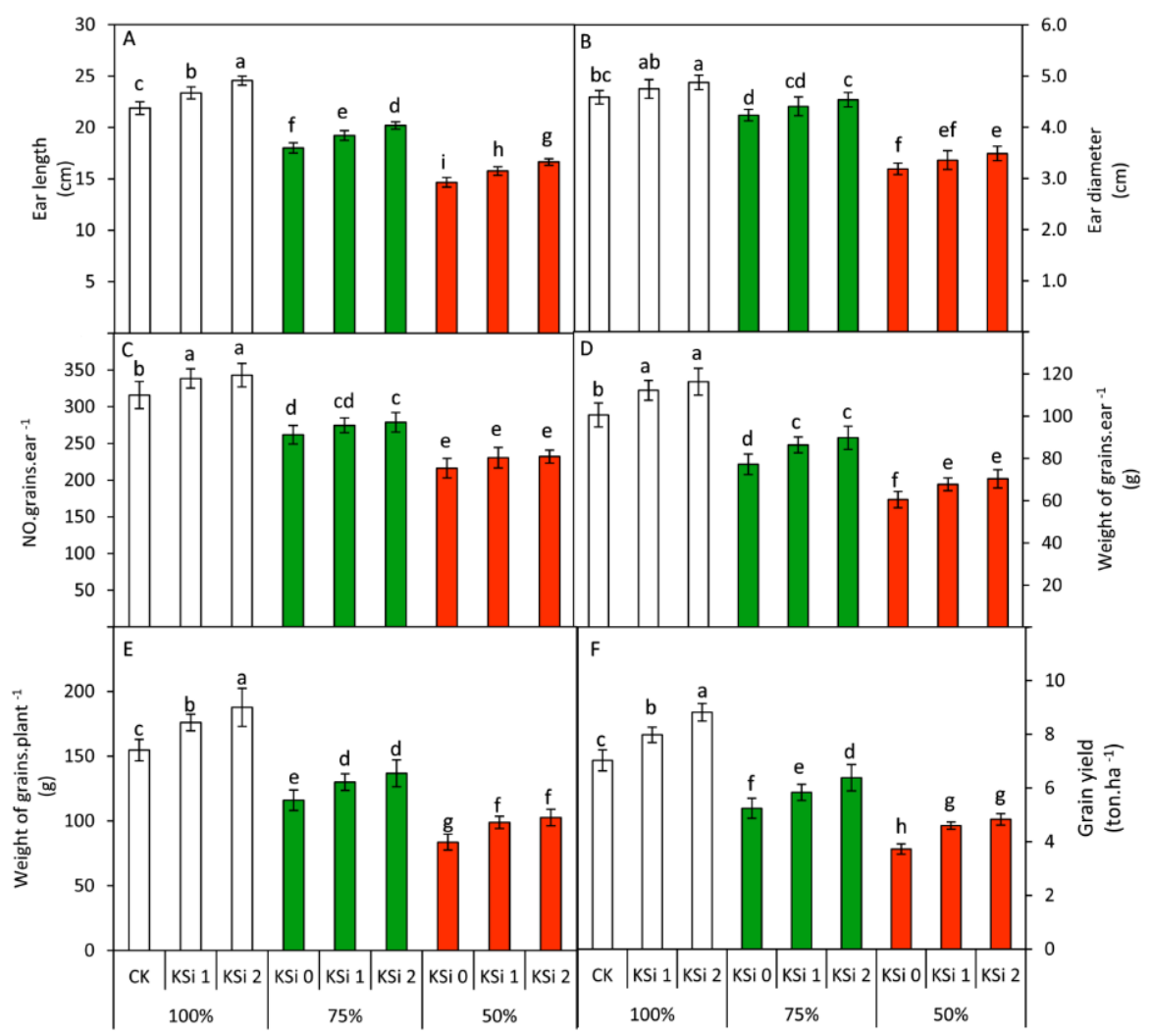

Figure 6. Yield and its parameters including averages of ear length (A), ear diameter (B), number of grains/ear (C) weight of grains/ear (D), weight of grains/plant $(\mathbf{E})$ and grain yield $\left(\mathrm{t} \mathrm{ha}^{-1}\right)(\mathbf{F})$ of the maize plants at $80 \mathrm{DAS}$ as influenced by the foliar application of $\mathrm{K}_{2} \mathrm{SiO}_{3}(0,1$ and $2 \mathrm{mM})$ under three irrigation regimes: $100 \%$ (white), $75 \%$ (green) and 50\% (orange) of water requirements. CK: well-watered control, $\mathrm{KSi}$ 0: $\mathrm{K}_{2} \mathrm{SiO}_{3}$-untreated plants, $\mathrm{KSi} 1: \mathrm{K}_{2} \mathrm{SiO}_{3}(1 \mathrm{mM})$ and $\mathrm{KSi} 2: \mathrm{K}_{2} \mathrm{SiO}_{3}(2 \mathrm{mM})$. Data of the two seasons of 2018 and 2019 were subjected to combined analysis. Means were presented \pm SD. Different letters are significant differences, according to Duncan's multiple range tests $(p<0.05)$.

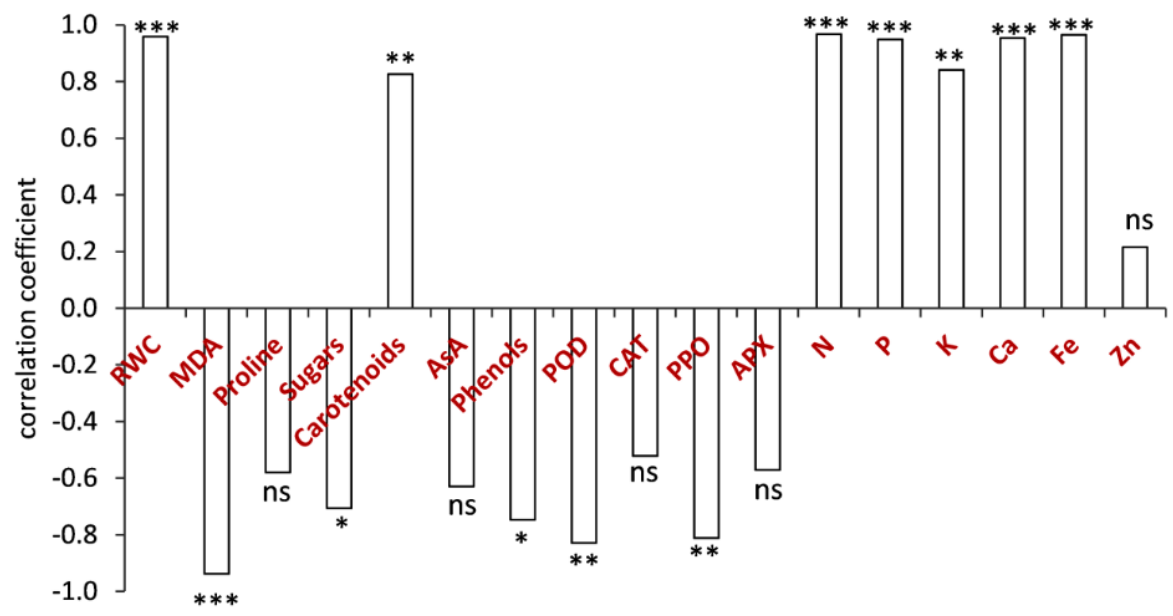

Figure 7. Relationship between the grain yield of maize crop and RWC, MDA, osmolytes, nonenzymatic antioxidants, antioxidant enzymes and mineral nutrients as influenced by the foliar application of $\mathrm{K}_{2} \mathrm{SiO}_{3}(0,1$ and $2 \mathrm{mM})$ under three different irrigation regimes (100, 75 and $50 \%$ of water requirements). Data of the two seasons of 2018 and 2019 were subjected to combined analysis. ns: not significant, ${ }^{*} p \leq 0.05,{ }^{* *} p \leq 0.01$ and ${ }^{* * *} p \leq 0.001$. 


\section{Discussion}

Under semiarid conditions, deficit irrigation is thought to be one of the most limiting factors that can restrict plant growth and productivity. In this study, soil analysis and climatic data showed that maize was exposed to high solar radiation and air temperatures with no precipitation during the cultivation periods in the two seasons. All of these factors exhibited drought stress on the maize plants during this study. It is well documented that drought stress reduces the growth of many plant species due to the restriction of cell division and differentiation [44]. In this study, reducing irrigation level exhibited significant decreases in shoot dry weight, root dry weight and LAI of the water-stressed plants (Figure 1). These reductions could be attributed to the disruption that occurred in the photosynthetic process through the degradation of pigments, limitation of stomatal conductance and decreasing the photochemical quantum yield $[8,45]$. On the other hand, root/shoot ratio as dry weight was unaffected under deficit irrigation (Figure 1). These results were in agreement with those obtained by Ma et al. [46], and may imply that phloem transport and leaf carbon exportation were less sensitive to water deficit under the circumstances of this study.

The positive effect of $\mathrm{K}_{2} \mathrm{SiO}_{3}$ on the shoot, root dry weight and LAI in the water-deficit stressed plants could be attributed to the synergistic effect of both $\mathrm{K}$ and $\mathrm{Si}$ on photosynthesis and production of assimilates [20,47]. In the present study, deficit irrigation negatively affected RWC while the $\mathrm{K}_{2} \mathrm{SiO}_{3}$ applications significantly mitigated this effect (Figure 2). Applied K positively affected leaf water content under stress conditions by maintenance of turgor potential and enhancing the integrity of cell membranes [48]. Additionally, Si could improve RWC by decreasing the rate of transpiration [49]. Lipid peroxidation is considered a pervasive biochemical response to stress in plant species due to the uncontrolled release of ROS [8]. Applied K and/or Si can promote the antioxidant capacity of the stressed plants $[20,21]$. This response may explain the significant decrease of MDA in the treated plants with $\mathrm{K}_{2} \mathrm{SiO}_{3}$ under water-stressed conditions (Figure 2). Proline is considered a compatible osmolyte and one of the most contributing factors that maintain intracellular redox homeostasis under stress conditions [50]. Moreover, under drought stress, proline has a crucial role in protecting the integrity of cell membranes and osmotic adjustments that allow the plant to uptake water [50,51]. Soluble sugars are the second compatible osmolytes that were determined in this investigation. The accumulation of soluble sugars during water deficit irrigation could be due to the up-regulation of genes involved in the starch-sucrose pathway [52,53]. All of the above-mentioned responses may explain the dramatic accumulation of proline and soluble sugars in the water-stressed plants under the circumstances of this study (Figure 2). The exogenous application of $\mathrm{K}_{2} \mathrm{SiO}_{3}$ resulted in a notable decrease in proline and a visible increase in soluble sugars. These effects indicate that $\mathrm{K}$ and/or Si may enhance the osmotic potential of leaves by stimulating the conversion of starch into soluble sugars, particularly up to the moderate level of irrigation [54,55]. Furthermore, the decrease of proline in the $\mathrm{K}_{2} \mathrm{SiO}_{3}$-treated plants may highlight the significance of $\mathrm{K}$ and/or $\mathrm{Si}$ in the protection of cell membranes and maintenance of RWC under deficit irrigation conditions (Figure 2).

Drought stress strongly affects the uptake of nutrients and it can restrict the translocation of some nutrients acropetally between plant organs [56]. Furthermore, it negatively affects active transport, permeability, and leaf transpiration [25,57]. In our study, plants exposed to moderate or severe stress exhibited a significant decline in $\mathrm{N}$ uptake (Figure $3 \mathrm{~A}$ ). This could be due to decreases in the activity of the N-uptake proteins (NRT1, NRT2) for inorganic nitrate $\left(\mathrm{NO}_{3}{ }^{-}\right)$and (AMT1) or ammonium $\left(\mathrm{NH}_{4}{ }^{+}\right)$[58]. Additionally, the availability of $\mathrm{N}$ could be reduced under the inadequate water supply [59]. The foliar application of $\mathrm{K}_{2} \mathrm{SiO}_{3}$ improved $\mathrm{N}$-uptake under stressed and normal conditions. Applied-K can ameliorate the deleterious effects of drought through the regulation of stomatal movement, increasing root cell elongation, osmotic adjustment and detoxification of ROS [48]. Furthermore, silicon improves photosynthesis, antioxidant activities, and absorption of mineral nutrients of many crops [21,47]. These effects could explain the positive influence of $\mathrm{K}_{2} \mathrm{SiO}_{3}$ on N-uptake in our study. Concerning phosphorus (P), it was decreased under severe level of deficit irrigation (50\%) (Figure $3 \mathrm{~B})$. This decrease may be attributed to reducing the concentration and/or 
activity of the P-uptake protein (PHT1) [58]. Moreover, under drought stress, P may be quickly converted into an immobile or insoluble form [60]. On the other hand, the increase in P-uptake prior to $\mathrm{K}_{2} \mathrm{SiO}_{3}$ application was significantly under severe and moderate stress. These effects imply that P-uptake in maize is highly dependent on the intensity of drought stress. Similarly, water stress markedly exhibited $\mathrm{K}$ deficiency compared to all $\mathrm{K}_{2} \mathrm{SiO}_{3}$ untreated plants (Figure 3C). This effect could be due to reduction in absorption by the roots and transpiration rate, which consequently reduced water and nutrient transport via xylem [60]. Applied- $\mathrm{K}_{2} \mathrm{SiO}_{3}$ significantly increases $\mathrm{K}$ content compared to the untreated plants. These results are in agreement with Jiang et al. [61], who found that the application of $\mathrm{K}$ can significantly increase its concentration in the different parts of maize plants such as grains and straw. In this study, Ca uptake was also inhibited by reducing water supply (Figure 3D). This impact was clear under the lower level of stress. Furthermore, the foliar application of $\mathrm{K}_{2} \mathrm{SiO}_{3}$ had no significant effect on $\mathrm{Ca}$ uptake under both examined treatments. Maize plants could be severely affected by Ca deficiency under drought condition because Ca is relatively an immobile nutrient and its uptake may require sufficient water supply [62].

Deficit irrigation manifestly suppressed the uptake of $\mathrm{Fe}$ in $\mathrm{K}_{2} \mathrm{SiO}_{3}$-untreated plants (Figure 3E). In contrast, applied $\mathrm{K}_{2} \mathrm{SiO}_{3}$, specifically at the highest concentration $(2 \mathrm{mM})$, improved Fe-uptake under both treatments. Silicon (Si) can mitigate the symptoms of Fe deficiency in different plant species including soybean, cucumber and rice $[63,64]$. It could play a crucial role in Fe uptake and its translocation from roots to the aerial parts of the plant $[65,66]$. This impact could be attributed to the fact that applied-Si can enhance citrate concentration, which acts as an Fe chelator and facilitates its movement through the xylem [67]. The translocation of $\mathrm{Zn}$ from roots to leaves may be inhibited by $\mathrm{Si}$ application. This effect may be due to the fact that $\mathrm{Si}$ precipitates with $\mathrm{Zn}$ as zinc silicate around the root epidermis [68], which may reduce $\mathrm{Zn}$ translocation via xylem [69].

Under drought stress, plants develop a wide array of complex antioxidant systems that integrated with each other simultaneously to reduce the accumulation of ROS and oxidative damages [70]. The foliar application of $\mathrm{K}_{2} \mathrm{SiO}_{3}$ induced dramatic improvement in the concentration of carotenoids under different investigated levels of irrigation. The increase of carotenoids under water stress due to $\mathrm{K}$ or Si supplementation could foster the antioxidant capacity of plants under deficit irrigation [71-74]. Under stress conditions, ascorbate (ASA) could be increased through the overexpression of its synthesis related-genes such as GMP, GME, GalUR, DHAR, and MDHAR [75]. In this study, AsA was substantially increased by reducing the irrigation level (Figure 4B). This response could help in scavenging ROS and inducing the ascorbate-glutathione cycle [8,76]. Phenolic compounds could also be involved in plant tolerance to drought stress and play a significant role as a sink for carbon under stress conditions $[77,78]$. These effects could explain the improvement in total soluble phenols by reducing the irrigation level in this study (Figure 4C). The increase in total soluble phenols by the treatments of $\mathrm{K}_{2} \mathrm{SiO}_{3}$ could be due to the effect of $\mathrm{Si}$, which may induce several changes in the phenolic compounds under abiotic and biotic stresses $[79,80]$.

In the present study, our results showed that deficit irrigation increased the activities of POD, CAT, PPO and APX in the leaves of maize plants (Figure 5). These findings could reflect the integrated regulation between these enzymes in the tolerance of maize plants to water stress. Exogenous applications of $\mathrm{K}_{2} \mathrm{SiO}_{3}$ induced a synergistic effect leading to an increase in the activities of all studied antioxidant enzymes under deficit irrigation levels. Previous reports showed that K and/or Si could enhance the antioxidant capacity of plants under stress conditions [20,21]. In this study, these effects were confirmed by the enhancement of RWC and reduction of MDA.

It is well documented that water stress has several deleterious influences on the productivity of maize plants $[17,81]$. It can affect different metabolic pathways, photosynthesis and translocation of many metabolites required for grain filling [81]. Furthermore, water stress can increase the potential for unsuccessful pollination and poor kernel setting of maize by affecting the anthesis and silking stages [82]. In this study, reducing irrigation levels reduced the yield of grains (Figure 6). Applications of $\mathrm{K}_{2} \mathrm{SiO}_{3}$ not only relatively reversed these adverse effects but also increased the ultimate yield of 
grains under water stress. These findings could be correlated with corresponding changes in several biochemical and physiological aspects that were found during this work (Figure 7).

\section{Conclusions}

In this study, it was found that applied $\mathrm{K}_{2} \mathrm{SiO}_{3}$, particularly at $2 \mathrm{mM}$ as a foliar spray, may have several benefits on maize crops under limited irrigation supply. These effects were associated with several changes at physiological and biochemical levels, including adjustment of RWC and osmolytes, alleviation of oxidative damage and reduction of cell membrane dysfunction, as well as enhancement of nutrient uptake of and regulation of several nonenzymatic and enzymatic antioxidant systems. These results could provide a link between the protective role of $\mathrm{K}_{2} \mathrm{SiO}_{3}$ against drought stress and the eventual yield of grains, especially under semiarid conditions.

Author Contributions: Conceptualization, M.F.M.I., H.A., R.F., G.A.E.-S., A.M.E.-S., M.H. and A.E.; methodology, H.A.E.-G., M.F.M.I., H.A., W.N.H., R.F. and G.A.E.-S.; software, A.M.E.-S., H.A.E.-G., M.H., W.H. and A.E.; validation, M.F.M.I., H.A., H.A.E.-G., R.F., G.A.E.-S., A.M.E.-S., M.H., W.N.H. and A.E.; formal analysis, M.F.M.I., H.A., R.F. and A.E.; investigation, A.M.E.-S., M.H. and W.N.H.; resources, M.F.M.I., H.A., R.F., G.A.E.-S., A.M.E.-S. and A.E.; data curation, M.F.M.I., H.A., R.F., G.A.-E.S., A.M.E.-S., M.H. and W.N.H.; writing-original draft preparation, M.F.M.I., H.A., R.F., G.A.-E.S. and A.E.; writing-review and editing, M.F.M.I., H.A.E.-G., H.A., A.A.E.-Y., R.F., G.A.E.-S., A.M.E.-S., M.H., W.N.H. and A.E. All authors have read and agreed to the published version of the manuscript.

Funding: The authors are grateful to the Researchers Supporting Project number (RSP-2020/53), King Saud University, Riyadh, Saudi Arabia.

Conflicts of Interest: The authors declare no conflict of interest.

\section{References}

1. Gallart, F.; Solé, A.; Puigdefábregas, J.; Lázaro, R. Badland Systems in the Mediterranean; John Wiley \& Sons, Ltd.: Chichester, UK, 2002; pp. 299-326.

2. Lal, R. Soil carbon sequestration impacts on global climate change and food security. Science 2004, 304, 1623-1627. [CrossRef] [PubMed]

3. Elkeilsh, A.; Awad, Y.M.; Soliman, M.H.; Abu-Elsaoud, A.; Abdelhamid, M.T.; El-Metwally, I.M. Exogenous application of $\beta$-sitosterol mediated growth and yield improvement in water-stressed wheat (Triticum aestivum) involves up-regulated antioxidant system. J. Plant Res. 2019, 132, 881-901. [CrossRef]

4. Alhaithloul, H.A.; Soliman, M.H.; Ameta, K.L.; El-Esawi, M.A.; Elkelish, A. Changes in Ecophysiology, Osmolytes, and Secondary Metabolites of the Medicinal Plants of Mentha piperita and Catharanthus roseus Subjected to Drought and Heat Stress. Biomolecules 2020, 10, 43. [CrossRef] [PubMed]

5. Habib, N.; Ali, Q.; Ali, S.; Javed, M.T.; Zulqurnain Haider, M.; Perveen, R.; Shahid, M.R.; Rizwan, M.; Abdel-Daim, M.M.; Elkelish, A. Use of Nitric Oxide and Hydrogen Peroxide for Better Yield of Wheat (Triticum aestivum L.) under Water Deficit Conditions: Growth, Osmoregulation, and Antioxidative Defense Mechanism. Plants 2020, 9, 285. [CrossRef] [PubMed]

6. Ibrahim, M.F.M.; Bondok, A.M.; Al-Senosy, N.K.; Younis, R.A. Stimulation Some of Defense Mechanisms in Tomato Plants under Water Deficit and Tobacco mosaic virus (TMV). World J. Agric. Sci. 2015, 11, 289-302.

7. Badr, A.M.; Shabana, E.F.; Senousy, H.H.; Mohammad, H.Y. Anti-inflammatory and anti-cancer effects of $\beta$-carotene, extracted from Dunaliella bardawil by milking. J. Food Agric. Environ. 2014, 12, $24-31$.

8. Abd Ellatif, S.; El-Sheekh, M.M.; Senousy, H.H. Role of microalgal ligninolytic enzymes in industrial dye decolorization. Int. J. Phytoremediat. 2020, 1-12. [CrossRef]

9. Abdel-Daim, M.M.; Dawood, M.A.O.; AlKahtane, A.A.; Abdeen, A.; Abdel-Latif, H.M.R.; Senousy, H.H.; Aleya, L.; Alkahtani, S. Spirulina platensis mediated the biochemical indices and antioxidative function of Nile tilapia (Oreochromis niloticus) intoxicated with aflatoxin B1. Toxicon 2020. [CrossRef]

10. Senousy, H.H.; Abd Ellatif, S.; Ali, S. Assessment of the antioxidant and anticancer potential of different isolated strains of cyanobacteria and microalgae from soil and agriculture drain water. Environ. Sci. Pollut. Res. 2020, 27, 18463-18474. [CrossRef]

11. Ahmad, I.; Ahmad, B.; Boote, K.; Hoogenboom, G. Adaptation strategies for maize production under climate change for semi-arid environments. Eur. J. Agron. 2020, 115, 126040. [CrossRef] 
12. Ranum, P.; Peña-Rosas, J.P.; Garcia-Casal, M.N. Global maize production, utilization, and consumption. Ann. N. Y. Acad. Sci. USA 2014, 1312, 105-112. [CrossRef]

13. Dhugga, K.S. Maize biomass yield and composition for biofuels. Crop Sci. 2007, 47, 2211-2227. [CrossRef]

14. Kleinmans, J.; Densley, R.; Hurley, T.; Williams, I. BRIEF COMMUNICATION: Feed value of maize silage in New Zealand-A review. In Proceedings of the New Zealand Society of Animal Production, Adelaide, Australia, 4-7 July 2016; pp. 100-102.

15. Ostrander, B.M. Maize Starch for Industrial Applications. In Industrial Crops: Breeding for BioEnergy and Bioproducts; Cruz, V.M.V., Dierig, D.A., Eds.; Springer: New York, NY, USA, 2015; pp. 171-189. [CrossRef]

16. de Araujo Rufino, C.; Fernandes-Vieira, J.; Martín-Gil, J.; Abreu Junior, J.D.S.; Tavares, L.C.; Fernandes-Correa, M.; Martín-Ramos, P. Water stress influence on the vegetative period yield components of different maize genotypes. Agronomy 2018, 8, 151. [CrossRef]

17. Mi, N.; Cai, F.; Zhang, Y.; Ji, R.; Zhang, S.; Wang, Y. Differential responses of maize yield to drought at vegetative and reproductive stages. Plant Soil Environ. 2018, 64, 260-267.

18. Martineau, E.; Domec, J.-C.; Bosc, A.; Dannoura, M.; Gibon, Y.; Bénard, C.; Jordan-Meille, L. The role of potassium on maize leaf carbon exportation under drought condition. Acta Physiol. Plant. 2017, $39,219$. [CrossRef]

19. Ul-Allah, S.; Ijaz, M.; Nawaz, A.; Sattar, A.; Sher, A.; Naeem, M.; Shahzad, U.; Farooq, U.; Nawaz, F.; Mahmood, K. Potassium Application Improves Grain Yield and Alleviates Drought Susceptibility in Diverse Maize Hybrids. Plants 2020, 9, 75. [CrossRef]

20. Du, Q.; Zhao, X.; Xia, L.; Jiang, C.; Wang, X.; Han, Y.; WANG, J.; YU, H.-Q. Effects of potassium deficiency on photosynthesis, chloroplast ultrastructure, ROS, and antioxidant activities in maize (Zea mays L.). J. Integr. Agric. 2019, 18, 395-406. [CrossRef]

21. Kim, Y.-H.; Khan, A.L.; Waqas, M.; Lee, I.-J. Silicon regulates antioxidant activities of crop plants under abiotic-induced oxidative stress: A review. Front. Plant Sci. 2017, 8, 510. [CrossRef]

22. Cooke, J.; Leishman, M.R. Consistent alleviation of abiotic stress with silicon addition: A meta-analysis. Funct. Ecol. 2016, 30, 1340-1357. [CrossRef]

23. dos Santos, M.S.; Sanglard, L.M.P.V.; Martins, S.C.V.; Barbosa, M.L.; de Melo, D.C.; Gonzaga, W.F.; DaMatta, F.M. Silicon alleviates the impairments of iron toxicity on the rice photosynthetic performance via alterations in leaf diffusive conductance with minimal impacts on carbon metabolism. Plant Physiol. Biochem. 2019, 143, 275-285. [CrossRef]

24. Snyder, G.H.; Matichenkov, V.V.; Datnoff, L.E. Silicon. In Handbook of Plant Nutrition; CRC Press: Boca Raton, FL, USA, 2007; pp. 551-568.

25. Cao, B.-L.; Wang, L.; Gao, S.; Xia, J.; Xu, K. Silicon-mediated changes in radial hydraulic conductivity and cell wall stability are involved in silicon-induced drought resistance in tomato. Protoplasma 2017, 254, 2295-2304. [CrossRef]

26. Eneji, A.E.; Inanaga, S.; Muranaka, S.; Li, J.; Hattori, T.; An, P.; Tsuji, W. Growth and nutrient use in four grasses under drought stress as mediated by silicon fertilizers. J. Plant Nutr. 2008, 31, 355-365. [CrossRef]

27. Yin, L.; Wang, S.; Liu, P.; Wang, W.; Cao, D.; Deng, X.; Zhang, S. Silicon-mediated changes in polyamine and 1-aminocyclopropane-1-carboxylic acid are involved in silicon-induced drought resistance in Sorghum bicolor $\mathrm{L}$. Plant Physiol. Biochem. 2014, 80, 268-277. [CrossRef] [PubMed]

28. Doorenbos, J. Guidelines for Predicting Crop Water Requirements; Food and Agriculture organization: Rome, Italy, 1975; Volume 24.

29. Iqbal, A.; Hidayat, Z. Potassium management for improving growth and grain yield of maize (zea mays L.) under moisture stress condition. Sci. Rep. 2016, 6, 34627.

30. Ünyayar, S.; Kelep, Y.; Ünal, E. Proline and ABA levels in two sunflower genotypes subjected to water stress. Bulg. J. Plant Physiol. 2004, 30, 34-47.

31. Heath, R.L.; Packer, L. Photoperoxidation in isolated chloroplasts: I. Kinetics and stoichiometry of fatty acid peroxidation. Arch. Biochem. Biophys. 1968, 125, 189-198. [CrossRef]

32. Bates, L.; Waldren, R.; Teare, I. Rapid determination of free proline for water-stress studies. Plant Soil 1973, 39, 205-207. [CrossRef]

33. Plummer, D.T. Practical Biochemistry; McGraw-Hill Book Company: New York, NY, USA, 1987; pp. $179-180$.

34. Cottenie, A.; Verloo, M.; Kiekens, L.; Velghe, G.; Camerlynck, R. Chemical Analysis of Plants and Soils; RUG. Laboratory of Analytical and Agrochemistry: Gent, Belgium, 1982; 63p. 
35. de Carvalho, L.M.J.; Gomes, P.B.; de Oliveira Godoy, R.L.; Pacheco, S.; do Monte, P.H.F.; de Carvalho, J.L.V.; Nutti, M.R.; Neves, A.C.L.; Vieira, A.C.R.A.; Ramos, S.R.R. Total carotenoid content, $\alpha$-carotene and $\beta$-carotene, of landrace pumpkins (Cucurbita moschata Duch): A preliminary study. Food Res. Int. 2012, 47, 337-340. [CrossRef]

36. A.O.A.C International. Official Methods of Analysis. Association of Official Analytical Chemists. Official Method 985.33. Vitamin C, (Reduced Ascorbic Acid) in Ready-to-Feed Milk Based Infant Formula 2, 6-Dichloroindophenol Titrimetric Method; A.O.A.C International: Washington, DC, USA, 1990; pp. 1108-1109.

37. Skalindi, F.; Naczk, M. Food phenolics: Sources, chemistry, effects, applications. Trends Food Sci. Technol. 1995, 7, 235-277.

38. Bradford, M.M. A rapid and sensitive method for the quantitation of microgram quantities of protein utilizing the principle of protein-dye binding. Anal. Biochem. 1976, 72, 248-254. [CrossRef]

39. Hammerschmidt, R.; Nuckles, E.; Kuć, J. Association of enhanced peroxidase activity with induced systemic resistance of cucumber to Colletotrichum lagenarium. Physiol. Plant Pathol. 1982, 20, 73-82. [CrossRef]

40. Cakmak, I.; Strbac, D.; Marschner, H. Activities of hydrogen peroxide-scavenging enzymes in germinating wheat seeds. J. Exp. Bot. 1993, 44, 127-132. [CrossRef]

41. Oktay, M.; Küfreviolu, I.; Kocaçalişkan, I.; Şaklrolu, H. Polyphenoloxidase from Amasya apple. J. Food Sci. 1995, 60, 494-496. [CrossRef]

42. Nakano, Y.; Asada, K. Hydrogen peroxide is scavenged by ascorbate-specific peroxidase in spinach chloroplasts. Plant Cell Physiol. 1981, 22, 867-880.

43. Snedecor, G.; Cochran, W. Statistical Methods, 7th ed.; Lowa: Ames, IA, USA, 1982.

44. Sacks, M.M.; Silk, W.K.; Burman, P. Effect of water stress on cortical cell division rates within the apical meristem of primary roots of maize. Plant Physiol. 1997, 114, 519-527. [CrossRef]

45. Zhou, R.; Kan, X.; Chen, J.; Hua, H.; Li, Y.; Ren, J.; Feng, K.; Liu, H.; Deng, D.; Yin, Z. Drought-induced changes in photosynthetic electron transport in maize probed by prompt fluorescence, delayed fluorescence, P700 and cyclic electron flow signals. Environ. Exp. Bot. 2019, 158, 51-62. [CrossRef]

46. Ma, X.; He, Q.; Zhou, G. Sequence of Changes in Maize Responding to Soil Water Deficit and Related Critical Thresholds. Front. Plant Sci. 2018, 9, 511. [CrossRef]

47. Chen, W.; Yao, X.; Cai, K.; Chen, J. Silicon alleviates drought stress of rice plants by improving plant water status, photosynthesis and mineral nutrient absorption. Biol. Trace Elem. Res. 2011, 142, 67-76. [CrossRef]

48. Wang, M.; Zheng, Q.; Shen, Q.; Guo, S. The critical role of potassium in plant stress response. Inter. J. Mol. Sci. 2013, 14, 7370-7390. [CrossRef]

49. Amin, M.; Ahmad, R.; Ali, A.; Hussain, I.; Mahmood, R.; Aslam, M.; Lee, D.J. Influence of silicon fertilization on maize performance under limited water supply. Silicon 2018, 10, 177-183. [CrossRef]

50. Abdelaal, K.A.; EL-Maghraby, L.M.; Elansary, H.; Hafez, Y.M.; Ibrahim, E.I.; El-Banna, M.; El-Esawi, M.; Elkelish, A. Treatment of Sweet Pepper with Stress Tolerance-Inducing Compounds Alleviates Salinity Stress Oxidative Damage by Mediating the Physio-Biochemical Activities and Antioxidant Systems. Agronomy 2019, 10, 26. [CrossRef]

51. Szepesi, Á.; Szőllősi, R. Mechanism of proline biosynthesis and role of proline metabolism enzymes under environmental stress in plants. In Plant Metabolites and Regulation Under Environmental Stress; Elsevier: Amsterdam, The Netherlands, 2018; pp. 337-353.

52. Das, A.; Rushton, P.J.; Rohila, J.S. Metabolomic profiling of soybeans (Glycine max L.) reveals the importance of sugar and nitrogen metabolism under drought and heat stress. Plants 2017, 6, 21. [CrossRef] [PubMed]

53. Kim, S.-W.; Lee, S.-K.; Jeong, H.-J.; An, G.; Jeon, J.-S.; Jung, K.-H. Crosstalk between diurnal rhythm and water stress reveals an altered primary carbon flux into soluble sugars in drought-treated rice leaves. Sci. Rep. 2017, 7, 1-18. [CrossRef]

54. Hajiboland, R.; Cheraghvareh, L.; Poschenrieder, C. Improvement of drought tolerance in tobacco (Nicotiana rustica L.) plants by silicon. J. Plant Nutr. 2017, 40, 1661-1676. [CrossRef]

55. Zahoor, R.; Zhao, W.; Abid, M.; Dong, H.; Zhou, Z. Potassium application regulates nitrogen metabolism and osmotic adjustment in cotton (Gossypium hirsutum L.) functional leaf under drought stress. J. Plant Physiol. 2017, 215, 30-38. [CrossRef] [PubMed]

56. Hu, Y.; Schmidhalter, U. Drought and salinity: A comparison of their effects on mineral nutrition of plants. J. Plant Nutr. Soil Sci. 2005, 168, 541-549. [CrossRef] 
57. Arve, L.; Torre, S.; Olsen, J.; Tanino, K. Stomatal responses to drought stress and air humidity. In Abiotic Stress in Plants-Mechanisms and Adaptations; IntechOpen: London, UK, 2011. [CrossRef]

58. Bista, D.R.; Heckathorn, S.A.; Jayawardena, D.M.; Mishra, S.; Boldt, J.K. Effects of drought on nutrient uptake and the levels of nutrient-uptake proteins in roots of drought-sensitive and-tolerant grasses. Plants 2018, 7, 28. [CrossRef] [PubMed]

59. Bloem, J.; de Ruiter, P.C.; Koopman, G.J.; Lebbink, G.; Brussaard, L. Microbial numbers and activity in dried and rewetted arable soil under integrated and conventional management. Soil Biol. Biochem. 1992, 24, 655-665. [CrossRef]

60. Ge, T.-D.; Sun, N.-B.; Bai, L.-P.; Tong, C.-L.; Sui, F.-G. Effects of drought stress on phosphorus and potassium uptake dynamics in summer maize (zea mays) throughout the growth cycle. Acta Physiol. Plant. 2012, 34, 2179-2186. [CrossRef]

61. Jiang, W.; Liu, X.; Wang, Y.; Zhang, Y.; Qi, W. Responses to Potassium Application and Economic Optimum K Rate of Maize under Different Soil Indigenous K Supply. Sustainability 2018, 10, 2267. [CrossRef]

62. Naeem, M.; Naeem, M.S.; Ahmad, R.; Ihsan, M.Z.; Ashraf, M.Y.; Hussain, Y.; Fahad, S. Foliar calcium spray confers drought stress tolerance in maize via modulation of plant growth, water relations, proline content and hydrogen peroxide activity. Arch. Agron. Soil Sci. 2018, 64, 116-131. [CrossRef]

63. Gonzalo, M.J.; Lucena, J.J.; Hernández-Apaolaza, L. Effect of silicon addition on soybean (Glycine max) and cucumber (Cucumis sativus) plants grown under iron deficiency. Plant Physiol. Biochem. 2013, 70, 455-461. [CrossRef]

64. Rinny, S.; Rout, G. Effect of silicon interaction with nutrients in rice. J. Exp. Biol. Agric. Sci. 2018, 6, 717-731.

65. Carrasco-Gil, S.; Rodríguez-Menéndez, S.; Fernández, B.; Pereiro, R.; de la Fuente, V.; Hernandez-Apaolaza, L. Silicon induced Fe deficiency affects $\mathrm{Fe}, \mathrm{Mn}, \mathrm{Cu}$ and $\mathrm{Zn}$ distribution in rice (Oryza sativa L.) growth in calcareous conditions. Plant Physiol. Biochem. 2018, 125, 153-163. [CrossRef]

66. Hernandez-Apaolaza, L. Can silicon partially alleviate micronutrient deficiency in plants? A review. Planta 2014, 240, 447-458. [CrossRef]

67. Rellán-Álvarez, R.; Giner-Martínez-Sierra, J.; Orduna, J.; Orera, I.; Rodríguez-Castrillón, J.Á.; García-Alonso, J.I.; Abadía, J.; Álvarez-Fernández, A. Identification of a tri-iron (III), tri-citrate complex in the xylem sap of iron-deficient tomato resupplied with iron: New insights into plant iron long-distance transport. Plant Cell Physiol. 2010, 51, 91-102. [CrossRef] [PubMed]

68. Gu, H.-H.; Qiu, H.; Tian, T.; Zhan, S.-S.; Chaney, R.L.; Wang, S.-Z.; Tang, Y.-T.; Morel, J.-L.; Qiu, R.-L. Mitigation effects of silicon rich amendments on heavy metal accumulation in rice (Oryza sativa L.) planted on multi-metal contaminated acidic soil. Chemosphere 2011, 83, 1234-1240. [CrossRef] [PubMed]

69. da Cunha, K.P.V.; do Nascimento, C.W.A. Silicon effects on metal tolerance and structural changes in maize (zea mays L.) grown on a cadmium and zinc enriched soil. Water Air Soil Pollut. 2009, 197, 323. [CrossRef]

70. Laxa, M.; Liebthal, M.; Telman, W.; Chibani, K.; Dietz, K.-J. The role of the plant antioxidant system in drought tolerance. Antioxidants 2019, 8, 94. [CrossRef] [PubMed]

71. Kanai, S.; Moghaieb, R.E.; El-Shemy, H.A.; Panigrahi, R.; Mohapatra, P.K.; Ito, J.; Nguyen, N.T.; Saneoka, H.; Fujita, K. Potassium deficiency affects water status and photosynthetic rate of the vegetative sink in green house tomato prior to its effects on source activity. Plant Sci. 2011, 180, 368-374. [CrossRef]

72. Shen, X.; Zhou, Y.; Duan, L.; Li, Z.; Eneji, A.E.; Li, J. Silicon effects on photosynthesis and antioxidant parameters of soybean seedlings under drought and ultraviolet-B radiation. J. Plant Physiol. 2010, 167, 1248-1252. [CrossRef] [PubMed]

73. Hassanein, R.A.; El Khawas, S.A.; Khafaga, H.S.; Abd El-Nabe, A.S.; Abd Elrady, A.S. Amelioration of Drought Stress on Physiological Performance of Pearl Millet (Pennisetum americanum) Plant Grown Under Saline Condition Using Potassium Humate and Silicon Source. Egypt. J. Exp. Biol. 2017, 13, 57-68. [CrossRef]

74. de Camargo, M.; Bezerra, B.; Holanda, L.; Oliveira, A.; Vitti, A.; Silva, M. Silicon fertilization improves physiological responses in sugarcane cultivars grown under water deficit. J. Soil Sci. Plant Nutr. 2019, 19, 81-91. [CrossRef]

75. Zhang, Y. Ascorbic Acid in Plants: Biosynthesis, Regulation and Enhancement; Springer Science \& Business Media: New York, NY, USA; Heidelberg, Germany; Dordrecht, The Netherlands; London, UK, 2013; pp. 111-114. [CrossRef] 
76. Bartoli, C.G.; Buet, A.; Grozeff, G.G.; Galatro, A.; Simontacchi, M. Ascorbate-glutathione cycle and abiotic stress tolerance in plants. In Ascorbic Acid in Plant Growth, Development and Stress Tolerance; Springer: Berlin/Heidelberg, Germany, 2017; pp. 177-200. [CrossRef]

77. Hashim, A.M.; Alharbi, B.M.; Abdulmajeed, A.M.; Elkelish, A.; Hozzein, W.N.; Hassan, H.M. Oxidative Stress Responses of Some Endemic Plants to High Altitudes by Intensifying Antioxidants and Secondary Metabolites Content. Plants 2020, 9, 869. [CrossRef] [PubMed]

78. Weidner, S.; Karolak, M.; Karamac, M.; Kosinska, A.; Amarowicz, R. Phenolic compounds and properties of antioxidants in grapevine roots [Vitis vinifera L.] under drought stress followed by recovery. Acta Soc. Bot. Pol. 2009, 78, 97-103. [CrossRef]

79. Malčovská, S.M.; Dučaiová, Z.; Maslaňáková, I.; Bačkor, M. Effect of silicon on growth, photosynthesis, oxidative status and phenolic compounds of maize (Zea mays L.) grown in cadmium excess. Water Air Soil Pollut. 2014, 225, 2056. [CrossRef]

80. Shetty, R.; Fretté, X.; Jensen, B.; Shetty, N.P.; Jensen, J.D.; Jørgensen, H.J.L.; Newman, M.-A.; Christensen, L.P. Silicon-induced changes in antifungal phenolic acids, flavonoids, and key phenylpropanoid pathway genes during the interaction between miniature roses and the biotrophic pathogen Podosphaera pannosa. Plant Physiol. 2011, 157, 2194-2205. [CrossRef]

81. Li, G.; Gao, H.; Zhao, B.; Dong, S.; Zhang, J.; Yang, J.; Wang, J.; Liu, P. Effects of drought stress on activity of photosystems in leaves of maize at grain filling stage. Acta Agron. Sin. 2009, 35, 1916-1922. [CrossRef]

82. Aslam, M.; Zamir, M.; Afzal, I.; Yaseen, M.; Mubeen, M.; Shoaib, A. Drought stress, its effect on maize production and development of drought tolerance through potassium application. Cercetari Agronomice in Moldova 2013, 46, 154.

(C) 2020 by the authors. Licensee MDPI, Basel, Switzerland. This article is an open access article distributed under the terms and conditions of the Creative Commons Attribution (CC BY) license (http://creativecommons.org/licenses/by/4.0/). 